九州大学学術情報リポジトリ

Kyushu University Institutional Repository

\title{
Selected Acanthoceratids from Hokkaido: Studies of the Cretaceous Ammonites from Hokkaido and Saghalien-XIX
}

Matsumoto, Tatsuro

Faculty of Science, Kyushu University

Muramoto, Tatsuo

Mikasa kaseki Dokokai (Mikasa Association of Non-professional Palaeontologists) : Leader

Takahashi, Takemi

Mikasa kaseki Dokokai (Mikasa Association of Non-professional Palaeontologists)

https://doi. org/10.5109/1543679

出版情報：九州大學理學部紀要：Series D, Geology. 19 (2)，pp.251-296，1969-01-25. Faculty of Science, Kyushu University バージョン:

権利関係 : 
Mem. Fac. Sci., Kyushu Univ. Ser. D. Geology, Vol. XIX, No. 2, pp. 251-296, text-figs. 1-9, pls. 25-38, Jan. 25, 1969

\title{
Selected Acanthoceratids from Hokkaido
}

(Studies of the Cretaceous Ammonites

from Hokkaido and Saghalien-XIX)

\author{
By \\ Tatsuro MATSUMoto \\ Tatsuo MURAMOTO and Takemi TAKAHASHI
}

\begin{abstract}
On the basis of our recent collections nine species of the Acanthoceratidae are described in this paper. They are two species of Mantelliceras, of which one is new, a magnificent new species of Sharpeiceras, two horned species of Acanthoceras, two species of Euomphaloceras, including a new, peculiar one, a species of Kanabiceras and a new species of a new genus related to Watinoceras.

The stratigraphic succession of these and also other, previously described species of acanthoceratids are summarized into a zonal scheme, with a conclusion of international correlation. In addition, brief remarks are given on the evolutional history of the Acanthoceratidae.
\end{abstract}

\section{Introduction}

Since one of us (T.M.), together with coworkers (MATsumoto et al., 1957), monographed the acanthoceratid ammonites from the Upper Cretaceous of Hokkaido, more specimens of the family have been assembled through our cooperative field work. Some of them are palaeontologically interesting and deserve description. They are also important for the international correlation of the Cretaceous strata. In the present paper we describe selected nine species which are assigned to Mantelliceras, Sharpeiceras, Acanthoceras, Euomphaloceras, Kanabiceras and a new genus. In connexion with the description of species, remarks are given on some genera, especially at length on Sharpeiceras, Euomphaloceras and a new genus related to Watinoceras.

It would be desirable to define a species on the basis of a sufficient number of specimens. For some reasons, however, ammonites of the Acanthocerataceae, except for a few special cases, do not occur so abundantly in Hokkaido. Only the first species, a new Mantelliceras, is represented by a fairly large number of specimens. We dare describe other eight species, including three new ones,

Manuscript received August 3, 1968.

Tatsuo Muramoto: Leader of the Mikasa Kaseki Dokokai [Mikasa Association of Non-professional Palaeontologists].

Takemi TAKAHASHI: Member of the same association. 
on the material of a limited number of specimens, and hope that the collections would be increased in the future by kind cooperation of the persons who have interests in the group. Anyhow, we wish that the results of our study may contribute for further improvement of knowledge.

In the following systematic descriptions one of us (T. MATSUMoTo) is primarily responsible for the identification of species and exclusively so for the description of certain genera. The other two of us are partly responsible for the observation, as well as for collecting and cleaning the specimens. The authorship of new taxa are indicated in the respective places, depending on the responsibility.

The described specimens from Hokkaido are mostly preserved at the Type-Specimen Room, Department of Geology, Kyushu University, Fukuoka, which is indicated by a symbol GK. in the text. Symbols or abbreviations for other repositories of the specimens which may be cited in the text are as follows :

AMNH.: American Museum of Natural History, New York

BEG.: Bureau of Economic Geology, University of Texas, Austin

BM.: British Museum (Natural History), London

GSI.: Geological Survey of India, Calcutta

GSM.: Geological Survey and Museum, London

GT.: Geological Institute, University of Tokyo

MNHN.: Museum National d'Histoire Naturelle, Paris

MUR.: MURAMoTo's private collection, Mikasa, Hokkaido

SM.: Sedgwick Museum, Cambridge, England

USNM.: United States National Museum, Washington, D. C.

For the localities of the described fossils, normally indicated by numbers, a reader is requested to refer to the already published papers, especially Matsumoto, 1965, figs. 1-5, and Matsumoto, 1942, pls. 10 and 12 . Some new localities are explained in the concluding remarks of this paper.

Acknowledgements-We thank Professor Emeritus Hisakatsu YABE for his encouragement and Messrs. Kikuwo MuRAmoto and Masanobu KIKUCHI for their cooperation in supplying us with some of their collections for study. We are indebted to Mr. C. W. Wright, Dr. M. K. Howarth, Dr. W. A. CobbaN, the late Dr. J. B. ReEside, Jr., Professor Raymond C. Moore, Professor C. R. STELCK, Dr. Jacques SorNAY and Mr. M. V. A. SASTRY, who gave necessary information and showed to one of us (T. MATsumoto) valuable specimens preserved in London, Denver, Washington, D. C., Lawrence (Kansas), Edmonton (Alberta), Paris and Calcutta. Our field work was undertaken by facilities generously offered to us by the main staff of the Pombetsu Mine, Sumitomo Coal Mining Co. The work at Kyushu University was in part financially supported by the Grant-in-aid of the Ministry of Education. Lastly our particular thanks are due to Dr. Itaru HAYAMI and Miss Yuko WADA who have assisted us in preparing the illustration and manuscript, and also to Dr. Ikuwo OBATA who has discussed with us about a taxonomic problem. 


\section{Systematic Descriptions}

Family Acanthoceratidae DE GRossouvRE, 1894

Subfamily Mantelliceratinae HYATT, 1903

Genus Mantelliceras HYATT, 1903

Type-species.-Ammonites mantelli J. SowERBY, 1814

Remarks. - The description of the generic diagnosis, with a discussion on the affinity, has already been given (Матsumoto et al., 1957, p. 5). It has been, furthermore, noted (MATSUmoto et al., 1966) that Submantelliceras SPATH, 1923, as well as Utaturiceras WRIGHT, 1956, should be separated from Mantelliceras as distinct genera.

In addition to a rare species, Mantelliceras (?) nagaoi Matsumoto, Saito and FUKUDA, 1957, from the Abeshinai area of Teshio Province, there are at least three species from the Ikushumbets area, Ishikari Province, of which two are described in this paper.

Mantelliceras japonicum Matsumoto, MURAMoto and TAKahashi, sp. nov.

Pl. 25, Figs. 1-2; Pl. 26, Figs. 1-3; Pl. 27, Figs. 1-2; Text-figs. 1-2

Material.-The holotype is GK. H5428 [Mu. 12716], from loc. Ik. 1100, representing a mature stage; paratypes GK. H5594, from loc. Ik. 1065g, H5609, H5427, H5426, H5560, and H5559, from loc. Ik. 1100, representing various growth-stages (Coll. MuRAmoto and MATsumoto). There are other examples from loc. Ik. 1054 and Ik. 1100, of which three of MURAMото's collection are mentioned below.

Specific diagnosis.-The shell is of moderate size, attaining to about $140 \mathrm{~mm}$. at the full-growth stage. The adult body-whorl occupies at least a half volution.

Whorls are moderately involute in the young shell, embracing about two thirds (in height) of the inner whorl, but the adult body-whorl becomes evolute. The umbilicus is of moderate size, about 30 to 36 percent of the shell diameter, becoming larger in the adult shell. It is surrounded by a steep wall.

The whorl is nearly as broad as high or somewhat higher than broad, becoming more compressed at the adult stage. The intercostal whorl section is subelliptical, having a moderately arched venter, rather flat or very gently convex flanks and more or less rounded umbilical shoulders. The costal section of the tuberculate immature whorl is roughly trapezoid-polygonal, being broadest between the upper umbilical tubercles. The costal section of the adult whorl is subelliptical, being similar to the intercostal section.

The shell is nearly smooth at the early immature stage, up to the diameter of about $5 \mathrm{~mm}$. The rest, main part of the phragmocone is ornamented with moderately strong and distant ribs and fairly strong tubercles. The ribs are at first prorsiradiate especially near the umbilical margin and become nearly rectiradiate in the main part of the septate whorl. The ribs are separated by 

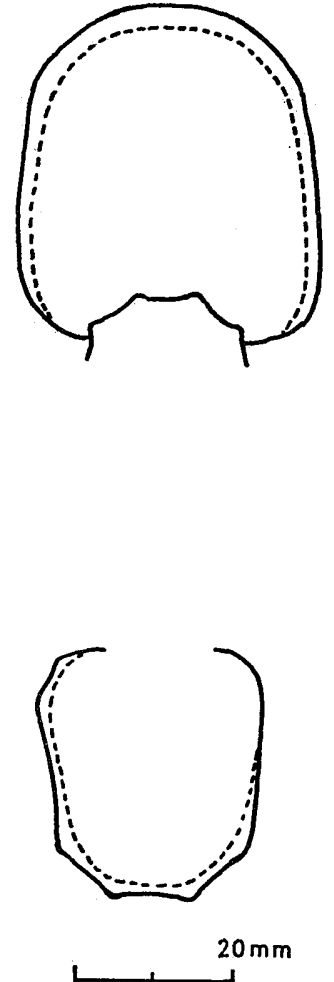

Fig. 1. Mantelliceras japonicum Matsumoto, MuramoTo and TAKAHASHI, n. sp. Whorl-section of the holotype, GK. H5428. (T. MAT. delin.)

somewhat wider interspaces. They are alternately long and short. A long rib on one side may be extended to a short one on the other side and vice versa. The short ribs are free from the umbilical tubercles, while the long ribs are provided with two umbilical tubercles, of which the upper one is prominent and the lower one is less so or sometimes very faint. The two tubercles are separated at variable distance depending on individuals, but the distance is in any case clearly shorter than that between the upper umbilical and the lower ventrolateral tubercles and is nearly as long as or shorter than that between the upper and the lower ventrolateral ones. The upper ventrolateral tubercle is somewhat clavate and normally stronger than the lower one. The distance between the outer ventrolateral tubercles on both sides of the siphonal area is nearly as short as or somewhat wider than that between the upper and the lower ventrolateral ones. The ribs straightly connect the two upper ventrolateral tubercles across the siphonal area, although with slight lowering and broadening.

The tubercles begin to be weakened at a diameter of about $80 \mathrm{~mm}$., i.e. at the last stage of the phragmocone or at the beginning of the adult body-whorl, and finally disappear in the last part of the body-whorl, although the upper umbilical and the lower ventrolateral ones may persist as low bulges on the ribs for some period. In the earlier part of this weakly or non-tuberculate whorl ribs are still alternately long and short. A long one on one side may be extended to a short one on the other. In the last part all the ribs are almost equally long. In the adult whorl some of the ribs are more or less projected near the umbilical margin, but on the main part of the flank and on the venter they are nearly rectiradiate or occasionally even slightly rursiradiate. They are moderately broad and elevated, crossing the venter without weakening. They are separated by slightly wider interspaces.

Sutures are of typical Mantelliceras type, having two broad, rather massive, bipartite lateral saddles and narrower lobes, with less deep and less numerous minor incisions. $\mathrm{E}$ is the longest; $\mathrm{L}$ is nearly as deep as $\mathrm{E}$ and asymmetrically trifid or apparently bifid at the bottom; much smaller, two or two and a half auxiliary lobes are seen on the external part. The first lateral saddle is nearly twice as broad as the second, being situated on the zone of lower and upper ventrolateral tubercles. 


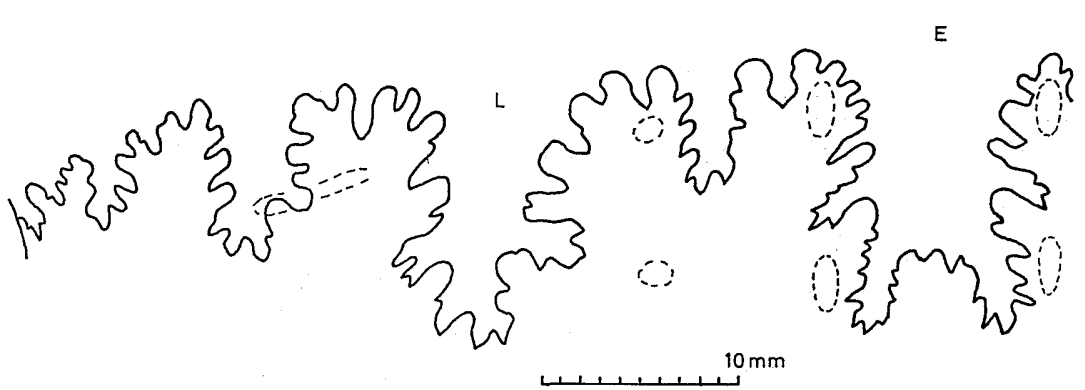

Fig. 2. Mantelliceras japonicum Matsumoto, Muramoto and TAKahashi, n. sp. External suture of the holotype, GK. H5428, at whorl-height=31 $\mathrm{mm}$. Dotted lines indicate the base of tubercles. (T. MAT. delin.)

Measurements.-

Specimen
GK. H5428 (c)
(ic)
$(-1 / 2$ vol.) (c)
GK. H5426 (c)
(ic)
(-1/2 vol.) (ic)
GK. H5427 (c)
MUR. Ik5001
MUR. 12443 (malform)
(-1/4 vol.) (c)
GK. K5609 (c)

\section{Diameter $118.6(1)$}

$76.0(1)$

$75.3(1)$

$73.2(1)$

$34.6(1)$

129.5

$109.0(1)$

$94.4(1)$

$80.0(1)$

(c) $=$ costal, (ic) $=$ intercostal

$\begin{array}{llll}\text { Umbilicus } & \text { Height } & \text { Breadth } & \text { B./H. } \\ 43.2(.36) & 44.0(.37) & 39.0(.33) & 0.88 \\ & 41.5 & 37.0 & 0.89 \\ 26.0(.34) & 29.5(.39) & 29.5(.39) & 1.00 \\ 23.5(.31) & 31.5(.42) & 32.9(.44) & 1.04 \\ 23.0(.31) & 30.5(.41) & 31.8(.43) & 1.04 \\ & 21.5 & 22.0 & 1.02 \\ 10.8(.31) & 13.8(.40) & 13.5(.39) & 0.98 \\ 45.8 & 47.5 & 41.0 & 0.86 \\ 41.0(.37) & 39.0(.36) & - & \\ 33.8(.35) & 38.3(.40) & 34.1(.36) & 0.9 \\ 25.6(.32) & 33.6(.42) & 30.0(.37) & 0.89\end{array}$

Variation.-On the basis of the observation on numerous specimens from loc. Ik 1100 , a bed in the recently excavated quarry, it is noticed that there is a considerable extent of variation in the shell form, from a comparatively thick-whorled one to a comparatively compressed one, and in the ornamentation, with variable persistency of the strongly tuberculate stages. The holotype and a paratype, GK. H5609, may represent the average form.

Comparison.-The present species is allied to Mantelliceras tuberculatum (MANTELL, 1822), represented by an example illustrated by SHARPE (1857, pl. 18, fig. 6 under Ammonites mantelli) (see Spath, 1926, p. 82, and WRIGHT and WRIGHT, 1951, p. 37), from the Lower Cenomanian Varians zone of England, and other examples illustrated by CollignoN (1964, p. 68, pl. 338, figs. 15111512 ; p. 69, pl. 339, figs. 1513-1517; p. 73, pl. 341, fig. 1526) from the Cenomanian zone of Mantelliceras mantelli of Madagascar, in the strongly tuberculate immature shell and the general aspects of the shell-form. It is distinguished from the latter by its more distant and less numerous ribs and on the average somewhat more compressed whorls, with less inflated flanks. The evolute shell-form at the adult stage may be another distinction.

In the general aspects of shell-form the present species resembles Mantelliceras mantelli (J. SoWERBY) (ShARPE, 1857, p. 40, pl. 18, fig. 7; WRIGHT, and Wright, 1951, p. 24), from the Lower Cenomanian Varians zone of England and the $M$. mantelli zone of Madagascar (CollignoN, 1964, p. 66, pl. 337, 
figs. 1506-1508; p. 68, pl. 338, figs. 1509-1510), but is distinguished by more distant and less numerous ribs and stronger tubercles. The latter seems to have a more involute shell and narrower umbilicus. In an example of M. mantelli in the collection from the Isle of Wight, England, and in some other examples a long rib on one side of the whorl is extended to a short one on the other side. This feature is the same as that seen in many examples of the present species, but it does not seem to be a well stabilized character, because there are exceptions. In the adult shell of $M$. mantelli the upper ventrolateral tubercles persist for a longer period than the lower and the alternating long and short ribs are seen even in a large shell (with diameter of about $140 \mathrm{~mm}$.), as illustrated by CoLLignoN (1954, pl. 337, fig. 1508). In the adult shell of our species, $M$. japonicum, the upper and lower ventrolateral tubercles are weakened nearly simultaneously, but the lower ones may rather persist for a slightly longer period, although they remain as indistinct low bulges: The equally long ribs, without intercalation of shorter ones, on the last part of the adult shell may be characteristic of $M$. japonicum.

An imperfectly preserved specimen, from Ikushumbets, which was previously described as Mantelliceras (?) sp. (MАтsumoto et al., 1957, p. 5, text-fig. 1) is probably a fragmentary example of the present species.

Occurrence.-Fairly commonly found in nodules at locs. Ik 1100 and Ik 1054 of the main valley of the Ikushumbets, zone of Mantelliceras japonicum (provisionally called the zone of Mantelliceras n. sp. by Matsumoto, 1965, fig. 5), sandstone of the lower part of unit IIb, Mikasa Formation [=Trigonia Sandstone of YABE, 1926], Lower Cenomanian. Specimens are found also on the right wall of the Shimo-ichi-no-sawa (locally called Torii-zawa) on the extension of the same zone.

\section{Mantelliceras cantianum SPATH} Pl. 27, Fig. 3; Pl. 28, Fig. 1 (?)

1857. Ammonites navicularis, Sharpe, p. 39, pl.18, fig.1, 2 (non MaNteli, 1822).

1926. Mantelliceras cantianum SpATH, p. 82.

? 1931. Mantelliceras budaense Adkins, p. 41, pl. 2, fig. 3; pl.4, fig. 10.

1951. Mantelliceras cantianum, WRIGHT and WRIGHT, p. 24.

1964. Mantelliceras cantianum, ColligNon, p. 80, pl. 344, fig. 1532-1534.

Types.-Holotype, BM. 36834 [=SHARPE, 1857, pl. 18, fig. 1] by original designation (SPATH, 1926a); paratype, BM.C. 5027 [=SHARPE, 1857, pl. 18. fig. 2], both of which were examined by one of us (T. Matsumoto).

Material.-GK. H5608, from loc. Ik 1100 (coll. T. TAKAhashI), is a typical example from Hokkaido. GK. H5610, from the same locality (coll. T. TAKAHASHI) could be referable to this species, but is provisionally called Mantelliceras sp. aff. $M$. cantianum (see below). There are several other examples in T. TAKAHASHI's private collection from the same locality.

Specific characters.-The shell is moderately large, nearly $120 \mathrm{~mm}$. in 
diameter in the holotype, moderately involute, about a half of the inner whorl being embraced by the outer one, and has a comparatively narrow umbilicus, which is nearly or less than 30 percent of the shell diameter.

The whorl is somewhat broader than high and roundish in section, having inflated flanks, subrounded umbilical shoulder and a broadly rounded venter.

The ribs are coarse, strong, and rather rigid. In the later stages of typical specimens they are separated by somewhat wider interspaces, being about 33 per whorl. Usually the ribs are alternately long and short, but occasionally two shorter ones may be intercalated between the longer ones. On the flank the longer ribs are somewhat stronger than the shorter ones, but on the venter they are almost equally strong.

The long ribs have two rows of tubercles around the umbilicus, one at the umbilical shoulder and the other on the lower part of the flank at a short distance from the umbilical shoulder. In most growth-stages every rib has two ventrolateral tubercles, lower one just at the ventrolateral shoulder and the upper one on the venter at some distance from the siphonal line. The tubercles are rounded at the base, although the upper ventrolateral tubercles may be somewhat clavate in certain growth-stages. There are no perceptible siphonal tubercles and the ribs cross the venter transversely, without notable projection nor weakening. On the last part of the adult whorl the tubercles are weakened and tend to be absorbed by the coarsened ribs.

The suture is of Mantelliceras type. The saddles are bifid and subrectangular in rough outline; the lobes are narrower than the saddles and moderately deep. Minor incisions are shallow, but the branches at the bottom of $\mathrm{L}$ are moderately deep.

\begin{tabular}{|c|c|c|c|c|c|c|}
\hline Specimen & & Umbilicus & & & & \\
\hline BM. 36834 & $116 \quad(1)$ & $34 \quad(.29)$ & $51 \quad(.44)$ & $55(+?)(.47)$ & 1.08 & 33 \\
\hline ВM. С. 5027 & $59 \quad(1)$ & $16(.27)$ & $26.5(.40)$ & $34 \quad(.57)$ & 1.3 & $34(?)$ \\
\hline GK. H5608 $\left(-20^{\circ}\right)$ & $63.0(1)$ & $17.0(.27)$ & $27.2(.43)$ & $33.5(.53)$ & 1.23 & 33 \\
\hline GK. H5610 & $97.5(1)$ & $29.5(.30)$ & $38.2(.39)$ & $37.2(.38)$ & 0.97 & 40 \\
\hline$\left(-90^{\circ}\right)$ & $88.3(1)$ & $26.5(.30)$ & $36.5(.41)$ & $41.0(.46)$ & 1.12 & 39 \\
\hline$\left(-180^{\circ}\right)$ & $68.0(1)$ & $19.0(.28)$ & $30.5(.45)$ & $35.0(.51)$ & 1.14 & 37 \\
\hline $\begin{array}{l}\text { SM. B35663 } \\
\text { for comparison }\end{array}$ & $96.5(1)$ & $27.0(.28)$ & $41.5(.43)$ & $46 \quad(+?)$ & 1.1 & 31 \\
\hline BEG. 17017 & $82.0(1)$ & $25.0(.30)$ & $35.3(.43)$ & $39.3(.48)$ & 1.11 & 23 \\
\hline
\end{tabular}

Variations.-On examining several British specimens, including the holotype, it is noticed that there is some extent of variation in the proportion between breadth and height, coarseness and density of the ribs and strength or persistency of tubercles. This is also recognized in a number of specimens from Hokkaido. One of them, GK. H5608, is very close to the paratype, BM. C. 5027 [=SHARPE, 1857, pl. 18, fig. 2], although its ribs are somewhat coarser in the preserved last part.

GK. H5610, among other specimens, deviates considerably from the holotype in its more crowded ribs and less persistency of ventrolateral tubercles, but is 
essentially of cantianum type in its inflated and subrounded shell form and coarse ribbing. Provisionally it may be called Mantelliceras sp. aff. $M$. cantianum, but it could be an extreme variant of $M$. cantianum. It is interesting that the last portion of the body-whorl of this specimen becomes somewhat evolute and is reduced in size, showing an unusually compressed form immediately behind the aperture.

On the other hand, the holotype of Mantelliceras budaense AdKINs (1931, p. 41, pl. 2, fig. 3; pl. 4, fig. 10), BEG. 17017, from the top bed of Buda Limestone, Texas, which one of us (T. MAT.) once studied, has widely separated, less numerous ribs (23 per whorl) but is otherwise essentially similar to the typical specimens of $M$. cantianum. Whether the above difference occurs constantly in the Texas specimens or not should be studied by further collection. It is, however, possible, that budaense could be a subspecies, or even a variety, of M. cantianum. A specimen from the Chalk Marl, Isle of Wight, preserved at Sandown Museum (Catalog. no. 1984), England, shows an intermediate feature in that it has 27 fairly distant ribs. It is, however, larger than BEG. 17017, about $125 \mathrm{~mm}$. in diameter, and on its last part of the outer whorl the tubercles are lost. Although it was labelled as Mantelliceras naviculare, it is probably an adult shell of $M$. cantianum.

CoLlignoN (1964, p. 80) has demonstrated certain variability in the character of umbilical tubercles for the Madagascar specimens of $M$. cantianum.

Comparison and affinity.-M. cantianum resembles $M$. mantelli (SowERBY) (see Sharpe, 1857, pl. 18, fig.7) and M. tuberculatum (MANTELL) (see SHARPe, 1857, pl. 18, fig. 6) but is distinguished by more rounded whoris and more robust, more rigid, coarser ornamentation.

The affinity of $M$. cantianum with certain species of Calycoceras has been noted by WRIGHT (personal talk) on the basis of such specimens as SM. B 35634, from Sandy Chloritic Marl, Eggerton Hill, Dorset (England), which is very similar to typical $M$. cantianum but has an incipient row of siphonal tubercles. An examples which show a similar feature are found in the collections from the Takambets (GK. H5619) and from Ik 1103, Mikasa Sandstone on the western wing, near Ikushumbets.

Occurrence.-Loc. Ik 1100, Katsurazawa quarry, Ikushumbets valley, Lower part of unit IIb, Mikasa Formation.

British specimens occur in the Varians Zone, Lower Cenomanian of southern England.

\section{Genus Sharpeiceras HYATT, 1903}

Type-species.-Ammonites laticlavius SHARPE, 1855 (original designation). Synonym.-Tlahualiloceras Kellum and MINTZ, 1962.

Generic characters.-A fairly large shell consists of rather evolute whorls, which are more or less higher than broad and typically subrectangular in 
section but may be modified to subelliptical (in intercostal section) at the adult stage of some species.

Ribs are nearly rectiradiate, single, and almost equally long in the typeand allied species, with tubercles at the umbilical shoulders, at or near the middle of the flanks, at the ventrolateral shoulders and on the venter at some distance from the siphonal line on every rib. In an exceptional case the upper lateral tubercle appears in addition to the fours. At certain stages of some species secondary ribs are branched or intercalated at or near the umbilical tubercles. On the adult body-whorl of some species the ventrolateral and sometimes also the ventral tubercles are strengthened to form horns.

Sutures are more deeply incised than that of Mantelliceras. Especially the lateral lobe is deep, being characterized by narrow and deep branches in its lower part. Saddles are less massive than in Mantelliceras. There are several, descending auxiliaries.

Remarks.-The following species are referred to the genus Sharpeiceras: S. laticlavium (SHARPE, 1855 ) (England, Madagascar, Tunisia?, Algeria?)

S. schlueteri HYATT, 1903 (Germany, Madagascar)

S. indicum (Kossmat, 1895) (India, Madagascar)

S. mexicanum (BösE, 1927). (Mexico)

S. occidentale BENAVIDES-CÁCERES, 1956 (Peru)

S. florencae SPATH, 1925 (S. Africa, Iran, Texas)

S. tlahualiloense (KeLlUM and MiNTZ, 1962) (Mexico)

S. vohipalense CollignoN, 1964 (Madagascar)

S. mosambiquense (Choffat, 1903) (SE. Africa)

S. kongo n. sp. (described below) (Japan)

S. mexicanum was described by BöSE (1927, p. 253, pl.10, fig. 6; pl.11, fig. 1) as a variety of $S$. laticlavium from the Buda Limestone, Coahuila, Mexico. It indeed resembles $S$. laticlavium, but is distinct in that the ribs are almost always bifurcated at the umbilical tubercle. In the holotype of $S$. laticlavium bifurcated or intercalated ribs are only discernible on the whorl with height of 25 to $35 \mathrm{~mm}$, but on the main part of its outer whorl the ribs are simple. $S$. mexicanum is also similar to $S$. indicum, but in the latter species the secondary ribs occur only in the late growth-stage and the ribs are rectiradiate as compared with the somewhat prorsiradiate ones in the Mexican species. The whorl of S. mexicanum is more compressed $(\mathrm{B} / \mathrm{H}=$ about 0.7$)$ than that of $S$. laticlavium $(\mathrm{B} / \mathrm{H}=0.84)$ but less so than that of $\mathrm{S}$. indicum $(\mathrm{B} / \mathrm{H}=0.6)$, so far as the type-specimens are concerned.

The tubercles of Sharpeiceras are normally in four rows, but in $S$. mosambiquense (CHOFFAT) (1903, p. 25, pl. 4, fig. 4; pl. 7, fig. 1) another row of tubercles is added to them in the upper lateral part.

As SPATH (1925, p. 199) pointed out, "Acanthoceras" laticlavium var. byzacenica PeRVINQUière (1907, p. 301 pl. 14, fig. 4) does not probably belong to Sharpeiceras. It may be a fragmentary immature shell of a species of Utaturiceras WRIGHT, 1956, which is more finely ribbed than $U$. vicinale (Stoliczka, 1864) (redefined by MATsumoto and SARKar, 1966, p. 297, pl. 32, 
fig. 1; pl. 33, figs. 1-3; text-figs. 1-4).

PERVINQUIERE's (1907, p. 302) example of "A. laticlavium" from Rebeiba, Tunisia, with "extremely developed twinned outer tubercles," might be a new species of Sharpeiceras, but, without seeing illustration or the specimen itself, it is difficult to give a definite conclusion.

HYATT's (1903, p. 111) assignment of Ammonites inconstans ScHLÜTER (1871, p. 7, pl. 3, figs. 1-5) to Sharpeiceras is not warrantable. ScHLÜTER's specimens are identical with Acompsoceras sarthense (GUÉRANGERE, 1867), as Pervinquikere (1907, p. 303) pointed out.

Specimens which should be referred to Mantelliceras were sometimes incorrectly referred to Sharpeiceras, but the generic distinction is clear, as is remarked below. Thus Ammonites cabardinensis SImonowiTch, BACEWITCH and SorokIN, 1874, which was reillustrated by ORLOV (1958, pl. 57, fig. 3) under the generic name Sharpeiceras, should be transferred to Mantelliceras, as Mantelliceras indianense HYATT, 1903, should be ketp in Mantelliceras.

Tlahualiloceras tlahualiloense KELLUM and MINTZ, 1962, on which Tlahualiloceras was set up by the two authors, is very close to Sharpeiceras florencae SPATH, 1925, and can be only distinguished by its somewhat more compressed whorls. There is, accordingly, no generic distinction between Sharpeiceras and Tlahualiloceras, and thus Tlahualiloceras KELLUM and MINTz, 1962, falls in a synonym of Sharpeiceras HYATT, 1903.

Comparison and affinities.-Sharpeiceras is allied to but distinguished from Mantelliceras HyATT, 1903. In Mantelliceras whorls are less evolute, ribs are as a rule alternately long and short, the ribs on the outer whorl are predominant over tubercles, which, accordingly, do not form horns, and furthermore, sutural saddles are more massive and lobes are broader and less deeply incised than in Sharpeiceras. In the typical species of Mantelliceras the umbilical tubercles are double, instead of forming an independent lateral tubercle. In some species, however, lateral tubercles are distinctly developed, as in $M$. indianense НYатT, 1903 (see StoliczKA, 1864, pl. 44, fig. 1; Collignon, 1964, pl. 345, fig. 1536), and $M$. lateretuberculatum CoLligNoN, 1964 (p. 94, pl. 348, fig. 1548; pl. 349, fig. 1552), and, thus, a Sharpeiceras like alignement of tubercles is shown.

Morphologically Mantelliceras could be ancestral to Sharpeiceras, but undoubted species of Mantelliceras are contemporary with those of Sharpeiceras. I am rather inclined to regard Submantelliceras SpATH, 1923 [type-species S. aumalense (COQUAND, 1862), from the basal part of the Cenomanian] as possibly a common ancestor of Mantelliceras and Sharpeiceras. As is discussed at length in another paper (MATSUMOTO et al., 1966), Submantelliceras is similar to but well distinguishable from the compressed subgroup of Mantelliceras (i.e. subgroup of $M$. hyatti), as well as from the typical group of Mantelliceras, by a particular pattern of sutures and other characters, although the type and other representative species of Submantelliceras are based on small, probably immature specimens. In the pattern of suture Sharpeiceras is closer to Submantelliceras than to typical Mantelliceras. In the shell form, characterized by evolute and subrectangular whorls, and general aspects of the ornament, species of 
Shar'peiceras could be derived through such species as Submantelliceras villei (COQUAND, 1862).

It is interesting to note that the holotype of S. laticlavium (SHARPE), GSM. 7755 , according to my observation, shows at a certain immature stage gently flexuous and somewhat prorsiradiate ribs* with inserted or branched secondaries and that of S. mexicanum (BösE) has more frequently bifurcated, prorsiradiate ribs. These characters may show an intimate relation to Submantelliceras, although the ribs of the two specimens are distinctly provided with lateral tubercles.

In connexion with this problem, it is requested to study early immature stages of Sharpeiceras. The hitherto described species of Sharpeiceras, including the new one in this paper, are always represented by more or less large specimens and no specimens of small, immature stages of the same species have been described in detail. Anyhow, typical species of Submatelliceras have involute whorls, more or less flexuous ribs with numerous secondaries, and no lateral tubercles.

In the hypernodosity of the body-whorl, somewhat compressed, subrectangular whorls, and sutural pattern, certain species of Sharpeiceras resemble the type-species [G. lozoi YounG, 1958] and allied species of Graysonites YounG, 1958, from the lower part of Lower Cenomanian (see MATSUMoTo, 1959c, p. 65-71). In Graysonites, however, the outer and inner ventrolateral tubercles are united into a ventrolateral horn on the body-whorl, the mediolateral tubercles are absent or very indistinct, the whorls are less evolute and the Submantelliceras like characters are persistent up to a considerable diameter of the septate whorl.

Occurrence.-Species of Sharpeiceras occur characteristically in the Lower Cenomanian. The genus shows world-wide distribution, although the hitherto described species (and specimens) are not so numerous as in the case of Mantelliceras.

Sharpeiceras kongo Matsumoto, Muramoto and Takahashi, sp. nov. Pl. 29, Fig. 1; Pl. 30, Fig. 1; Text-figs. 3-4

Material.-Holotype: T. Takahashi Coll. No. 425261, from loc. Ik 1100, Ikushumbets. Paratypes: GK. H5604 [Muramoto Coll.], a large but wholly septate specimen, from loc. Ik 1100, and T. TAKAHASHI Coll. No.405161, an incomplete and deformed specimen, from loc. Ik 1101 ("Mamushi-zawa"), close to the type-locality.

Etymology.-Kongo, a deity who is believed to guard Buddha against demons. The rigid and strongly ornamented aspect of this large ammonite reminds us of the figure of Kongo, exemplified by the well known sculpture in the temple of Todaiji, Nara.

Diagnosis.-The shell is large, nearly $300 \mathrm{~mm}$ in diameter at the adult

\footnotetext{
* The drawing in SHARPE $(1855$, pl. 14, fig. 1) does not quite correctly illustrate this
} feature. 


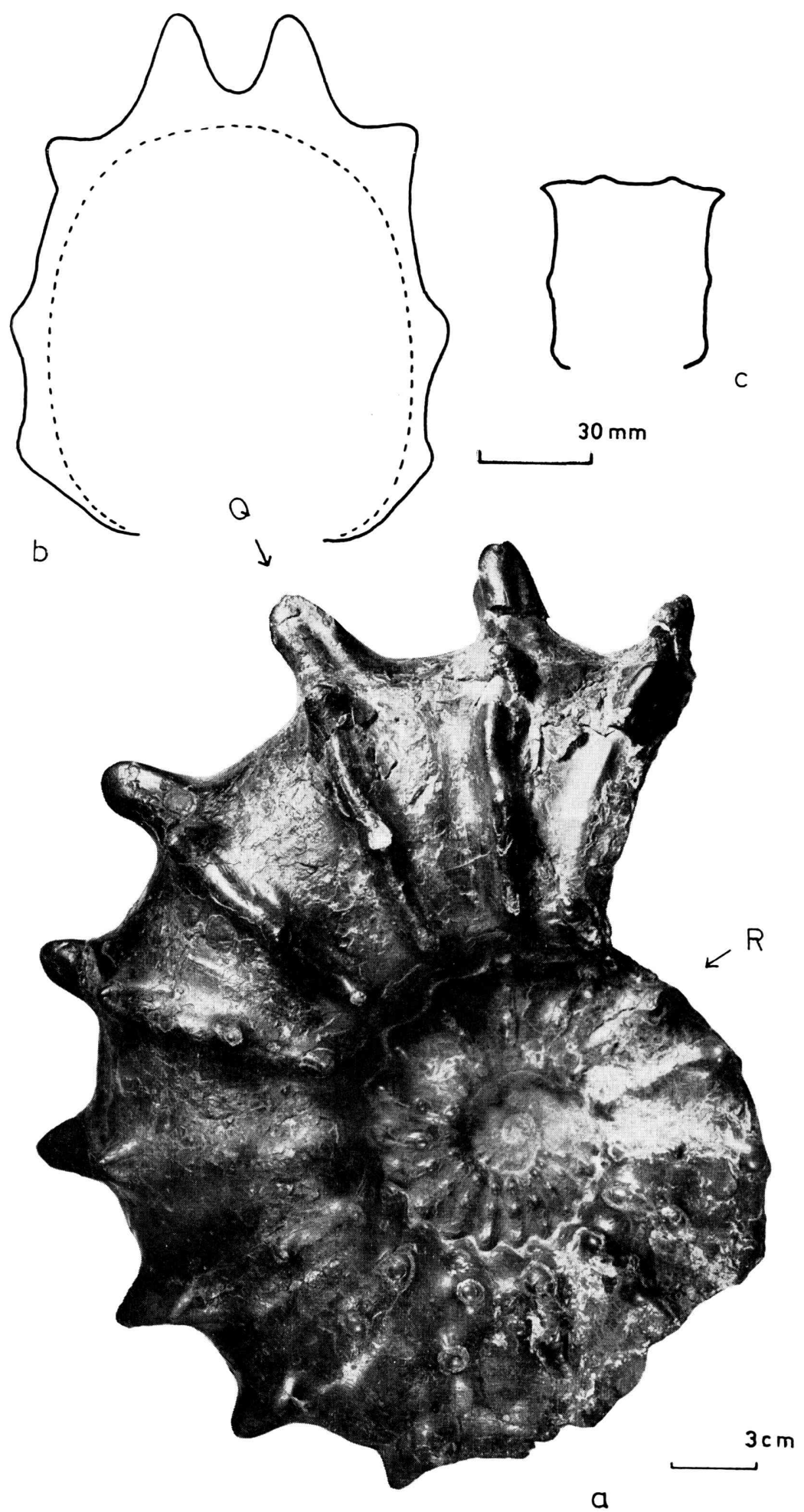

Fig. 3. Sharpeiceras kongo Matsumoto, Muramoto and TAKahashi, n. sp. Lateral view (a) and whorl-sections (b, c) at $Q$ and $R$. 
stage. Whorls are rather evolute, the outer one slightly embracing the ventral part of the inner one. The umbilicus is moderately deep and of moderate size, about one third of the entire shell diameter, as it is encircled by fairly rapidly increasing whorls. The body-whorl occupies about a half volution and its apertural end is somewhat reduced in breadth and height.

The septate whorl is nearly rectangular in section, having plane and parallel flanks and a rather flat venter. It is somewhat higher than broad. The adult body-whorl keeps the same proportion of height and breadth, about 10:8.5 on the average. It has, however, somewhat more rounded section, with gently inflated flanks and a moderately arched venter.

The ribs are nearly rectiradiate, occasionally slightly concave, and almost equally long at least in the outer two whorls. They are widely separated. Their distance regularly increases with growth. In the last entire whorl of the holotype there are only 15 ribs, of which 8 are on the body-whorl. The tubercles are in four rows on each side, of which the lateral one is a little closer to the umbilical one than to the ventrolateral one.

On the septate whorls ribs are moderately broad and rather low, while tubercles are predominant over ribs. The low ribs scarcely cross the venter. of the tubercles in four rows, the ventrolateral one is the most prominent, stretching somewhat sideward so as to lean against the steep wall of the outer whorl. The lateral and umbilical tubercles are of moderate intensity and rounded at their base. The ventral tubercles are low to moderately elevated, and somewhat clavate, with the highest point at the anterior part of the clavus. The paired ventral clavi on either side of the siphonal line are moderately separated. The shell may be slightly elevated on the siphuncle, as in some other acanthoceratids, but a distinct keel is never formed.

On the body-whorl the ribs are rigid and very strong, increasing their elevation with growth. They cross the venter. The tubercles are also enlarged and very prominent on the body-whorl. The ventrolateral tubercles are stronger than the lateral and the umbilical ones, forming smaller horns. The ventral tubercles are the most prominent, forming larger horns on the main part of the body-whorl. The paired ventral horns are characteristically approximated, with a V-shaped valley between them at the middle of the venter. They are upright in frontal (or back) view, and asymmetrically elevated in lateral view, with an almost vertical posterior wall and a moderately inclined anterior wall. Their base is elliptical, somewhat, but not much elongated spirally. On the anterolateral side of the horn a shallow depression may be discernible, which is extended from a very shallow furrow along the anterior foot of the steeply elevated rib. The horns on the rib near the apertural end are somewhat lower than those on the preceding rib.

The suture is deeply incised and of typical Sharpeiceras pattern (e.g. that illustrated by ScHLÜTER, 1872, pl. 7; figs. 7, 8 and by Kossmat 1895, pl. 24, fig. 6b) in which the large $L$ (first lateral lobe) has a narrow stem and deep branches at the bottom and on the sides. 


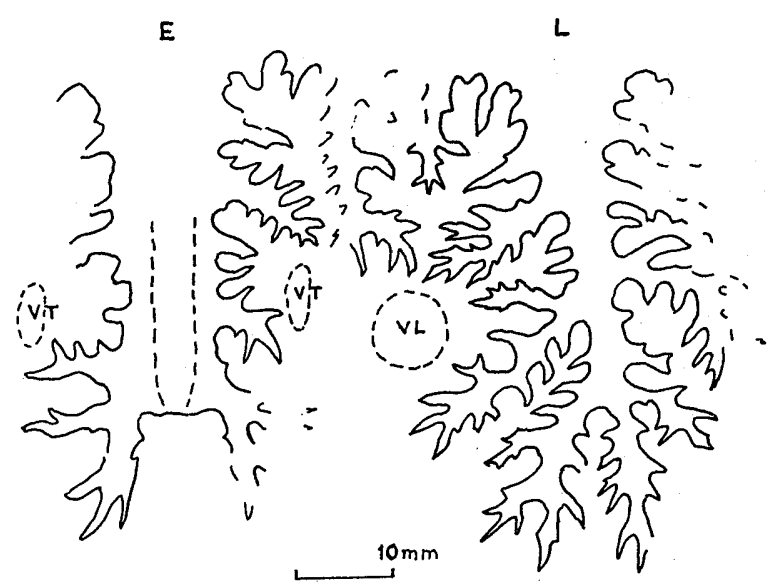

Fig. 4. Sharpeiceras kongo Matsumoto, MURAmoto and TAKAHAsHi, n. sp. Part of the external suture of the holotype at worl-height $=55 \mathrm{~mm}$.

(T. MAT. delin.)

Measurements (in $\mathrm{mm}$ ).-

\begin{tabular}{|c|c|c|c|c|c|}
\hline Specimen & Diameter & Umbilicus & Height & Breadth & B./H. \\
\hline \multicolumn{6}{|l|}{ Holotype of S. kongo } \\
\hline (1) (ic) & $286(1)$ & $103(.36)$ & $108(.38)$ & $87(.30)$ & 0.80 \\
\hline (2) (c) & $310(1)$ & $101(.33)$ & $143(.46)$ & $122(.39)$ & 0.85 \\
\hline (3) (ic) & $271(1)$ & $95(.35)$ & $108(.40)$ & $94(.35)$ & 0.87 \\
\hline (4) (ic) & $201(1)$ & $66(.32)$ & $84(.42)$ & $71(.35)$ & 0.84 \\
\hline (5) (ic) & $135(1)$ & $45(.33)$ & $55(.40)$ & $45(.33)$ & 0.82 \\
\hline \multicolumn{6}{|l|}{ Paratype } \\
\hline GK. H5604 (ic) & $250(1)$ & $85(.34)$ & $95(.38)$ & $76(.30)$ & 0.80 \\
\hline $\begin{array}{l}\text { For comparison, Ho } \\
\text { S. laticlavium } \\
\text { (meas. by MAT.) }\end{array}$ & $\begin{array}{l}\text { Tolotype of } \\
129(1)\end{array}$ & $35(.27)$ & $59(.45)$ & $50(.38)$ & $0.84(\mathrm{c})$ \\
\hline $\begin{array}{l}\text { S. florencae } \\
\text { (after SPATH)* }\end{array}$ & $\begin{array}{l}200(1) \\
160(1)(c) \\
100(1)\end{array}$ & $\begin{array}{l}66(.33) \\
51(.32) \\
30(.30)\end{array}$ & $\begin{array}{l}84(.42) \\
72(.45) \\
43(.43)\end{array}$ & $\begin{array}{l}76(.38) \\
66 .(.41) \\
36(.36)\end{array}$ & $\begin{array}{l}0.90 \\
0.91 \\
0.84\end{array}$ \\
\hline $\begin{array}{l}\text { S. vohipalense } \\
\text { (after CoLLIGNON) }\end{array}$ & $162(1)$ & $58(.36)$ & $66(.41)$ & $\begin{array}{l}50(.31) \\
67(.41)\end{array}$ & $\begin{array}{l}0.76(\mathrm{ic}) \\
1.0(\mathrm{c})\end{array}$ \\
\hline
\end{tabular}

(1): At the apertural end; (2) along the last third rib, about $45^{\circ}$ back from (1); (3) behind (2), between the ribs; (4) about $180^{\circ}$ back from (1); (5) about $270^{\circ}$ back from (1); (c): costal, (ic): intercostal.

* SpAtH's (1925, p. 198) indication of 0.38 for the height in proportion to the diameter of $200 \mathrm{~mm}$. is probably a misprint. Here the approximate measurements from the figure are indicated.

Comparison.-At least ten species of Sharpeiceras are known from various regions of the world, but for some reasons they are everywhere represented by a small number of specimens. Accordingly the extent of variation is not precisely described for each species. Under these circumstances comparisons are made with respect to the criteria which have been normally regarded as distinct enough for the specific separation, although some of the distinctions might be only subspecific. 
In the adult shell Sharpeiceras kongo resembles S. florencae SPATH (1925, p. 198, pl. 37), from the Cenomanian of "Maputoland", southeastern Africa, in somewhat inflated flanks, distant and strong ribs, and especially well developed ventrolateral and ventral horns of the body-whorl. The two species are also similar to each other in the shell-form of the septate stage, which is evolute, flattened on flanks, and subquedrate in section, having almost the same proportion of breadth to height as that of S. laticlavium (SHARPE). S. kongo has, however, much more distant and less numerous ribs (15 or 16 per whorl as compared with 25 or more in $S$. florencae) on the septate whorls, and more highly elevated ribs on the body-whorl than $S$. florencae. The approximated, strong ventral horns are, furthermore, characteristic of $S$. kongo.

The present species is somewhat similar to $S$. tlahuliloense (KELLUM and MinTZ) (1962, p. 276, pl. 6, fig. 1; pl. 7, figs. 1-2; pl. 8, fig. 1), from the Lower Cenomanian of Coahuila, Mexico, in the large, evolute shell, distant ribs on the body-whorl, and prominent outer tubercles. In the septate stages the Mexican species, like $S$. florencae, has more numerous and less distant ribs than $S$. kongo. In this respect and in the more rigid ribs and also the stronger horns on the body-whorl $S$. kongo is distinct from the Mexican species.

S. kongo is allied to $S$. vohipalense Collignon (1964, p. 104, pl. 354, fig. 1565), from the Lower Cenomanian of Madagascar, in the distant ribs and the strong tubercles. The ventral tubercles are particularly strengthened on the body-whorl of the former, while they are lowered and clavate on that of the latter. The adult whorl of $S$. kongo is much larger and more inflated than that of $S$. vohipalense. Thus the adult shell of the Madagascar species considerably resembles the septate shell of the Japanese one.

Sharpeiceras occidentale BENAVIDES-CÁCERES (1956, p. 465, pl. 54, figs. 5-6), from the Lower Cenomanian Mariella lewesiensis zone of Peru, is characterized by fairly approximated allocation of the paired ventral tubercles. In S. kongo, however, the ventral tubercles are approximated only on the adult body-whorl and normally separated on the septate whorls. S. kongo is, furthermore, distinguished from $S$. occidentale in its more inflated body-whorl, much more distant ribs, stronger tubercles, and especially the intensified ribbing and hypernodosity in the adult.

A highly crushed specimen, from the Miyanohara Sandstone of the Cretaceous sequence of the Ochi-Sakawa area, Shikoku, in the collection of the University of Tokyo, which one of us (MAT.) saw once but seems to be missing now, is smaller than the specimens from Hokkaido but has clavate ventral tubercles in addition to the less clavate ventrolateral and the bullate lateral and umbilical ones on each ribs. The ribs are of nearly equal length, about 13 within the preserved two thirds of the entire whorl, and separated by wider interspaces. A horn is preserved on one of the ventral tubercles of this small specimen. Thus the specimen is closely allied to, if not identical with, S. kongo, from Hokkaido. It has a smaller umbilicus, although the size is not exactly measurable, owing to the secondary deformation. 
This ammonite from the Miyanohara Sandstone, which can be temporarily called Sharpeiceras sp. aff. S. kongo, is associated with other ammonites and trigonians, of which an immature specimen of Mantelliceras is probably identical with Mantelliceras japonicum.

Occurrence.-The described three specimens were obtained from loc. Ik 1100 , Katsurazawa quarry, and adjacent loc. Ik 1101 on the northern wall of the V-shaped valley of the Ikushumbets, from the sandstone bed belonging to the $20 \mathrm{~m}$. unit in the lower part of IIb of the Mikasa Formation. It contains, among others, a number of specimens of Mantelliceras japonicum.

To the flank of the body-whorl of the holotype a few small flat valves of Anomia [?] sp. are attached, facing their beak to the dorsad orientation.

\section{Subfamily Acanthoceratinae DE GROSsouvre, 1894 \\ Genus Acanthoceras NeUMaYR, 1875}

Type-species.-Ammonites rhotomagense Defrance in BrongNiart, 1822, as designated by DE GRossouvre, 1894 (p. 27).

Remarks.-The generic diagnosis has been given recently (MATSUMoto and OBATA, 1966), with a discussion on the extent and variability of the genus. As stated on that occasion, the species with strong horns on the outer whorl are intimately related to the less strongly horned or normally tuberculated ones and it is not natural to separate merely on that account the two subgroups as disinct genera.

Few works have been devoted to make clear the extent of variation of Acanthoceras species. Even for Acanthoceras rhotomagense, the type-species itself, this is unfortunately true. Our present material is not either sufficient for this purpose, but we would not take the species concept of too little variability.

As has been mentioned by WRIGHT (1963, p. 605), there are certain species which are difficult to place in either Acanthoceras or Calycoceras. For the time being they are included in Acanthoceras. Examples are A. tapara WRIGHT, 1963, A. mirialampiense WRIGHT, 1963, and also A. hunteri Kossmat, 1895. No example of this kind of form is found in the present collection from Hokkaido.

\section{Acanthoceras amphibolum MoRRow}

PI. 31, Fig. 1

1935 Acanthoceras ? amphibolum MoRrow, p. 40, pl. 49, figs.1-4, 6; pl.51, figs. 3, 4; text-fi. 4.

1953. Acanthoceras hazzardi STEPHENSon, p. 201, pl. 48, figs. 1-2; pl. 49, fig. 4.

1966. Acanthoceras amphibolum, Matsumoto and OвAтA, p. 45, text-figs. 4-6.

1966. Acanthoceras hazzardi, MATSUMото and ОватA, p. 45, text-fig. 7.

Types.-MoRnow established this species on a large number of specimens, from two nearby localities in the upper Graneros Shale of Kansas, and illustrated five syntypes of different growth-stages, which one of us (T. MAT.) studied at the University of Kansas. 
As the shell shows a great change of characters with growth, it is difficult to select a lectotype.

Material.-GK. H5593, from loc. Ik 1051 (Coll. SHIBUYA, a school-boy of the Mikasa High School), and another specimen, T. TAKaHAshr's Coll. No. 424304 [Ik. TA4], from loc. Ik. 1102, are examples from Hokkaido.

Specific characters.-The shell is of moderate size, attaining to approximately $150 \mathrm{~mm}$. at the full-grown stage. It is not much involute, less than a third of the inner whorl being embraced by the outer one. It increases fairly rapidly and especially remarkably so in the young shell. Accordingly the umbilicus is at first fairly narrow and later becomes moderate, ranging from 23 to 30 percent of the entire shell diameter.

The whorl is nearly as high as broad, or slightly higher than broad, or vice versa, depending on individuals or on growth-stages. It is generally subquadrate in section, although the hypernodosity in the adult shell may modify the general aspect. The umbilical wall is high and very steep.

The ribs are weak or of moderate intensity. They are separated by wider interspaces, becoming more distant as the shell grows. They are at first slightly prorsiradiate and later nearly rectiradiate. The shorter ribs occur rather infrequently in the immature shell.

The tubercles are generally predominant over the ribs, especially so on the adult whorl where hypernodosity is remarkable. In the young shell the umbilical tubercles are bullate and highest at a point at some distance above the umbilical margin; the lower and upper ventrolateral and siphonal tubercles are nearly equidistant on the venter, and more or less clavate, of which the lower ventrolateral ones are somewhat more prominent than others. On the whorl of middle growth-stages, with diameters of about 40 to $65 \mathrm{~mm}$. (may be 50 to $75 \mathrm{~mm}$., in some individuals), the lower ventrolateral tubercles are gradually enlarged, while the upper ventrolateral and mid-ventral ones gradually weakened. Occasionally the weak and low ventral ribs are doubled, forming a loop at the lower ventrolateral tubercle. In such a case the upper ventrolateral and midventral, smaller tubercles are twice as numerous as the larger lower ventrolateral ones, but this character is by no means firmly settled, and one by one correspondence of the ventral tubercles can be also seen in some other parts. In addition the clavate mid-ventral tubercles may sometimes, but not always, form a low keel like elevation above the siphonal line, but this should not be called a distinct keel nor a firmaly established character.

In the mature shell, i.e. on the last part of the septate whorl and on the adult body-whorl, the weakened upper ventrolateral tubercle is united into a much enlarged lower ventrolateral tubercle, which becomes finally a ventrolateral horn. The horn stretches obliquely sideward and upward. The umbilical tubercle is also enlarged at this stage, with its highest point shifting upward to the lower lateral point. The ribs are much distant at this stage.

\section{Measurements.-}

$\begin{array}{cccccc}\text { Specimen } & \text { Diameter } & \text { Umbilicus } & \text { Height } & \text { Breadth } & \text { B./H. } \\ \text { Syntype (1) (c) } & 27.0(1) & 6.3(.23) & 14.8(.54) & 15.4(.57) & 1.04\end{array}$




\begin{tabular}{|c|c|c|c|c|c|}
\hline Syntype (2) (c) & 57.7 & $15.5(.27)$ & $25.7(.44)$ & 24.6 & 0.94 \\
\hline Syntype (3) (c) & Ca 95 & - & $39.0(.41)$ & $39.5(.41)$ & 1.01 \\
\hline (ic) & & & 37.5 & 35.5 & 0.94 \\
\hline Syntype (4) (c) & - & - & 46.0 & 45.5 & 0.99 \\
\hline (c) & - & - & 39.5 & 40.0 & 1.01 \\
\hline "A. hazzardi" & & & & & \\
\hline $\begin{array}{ll}\text { holotype } & \text { (c) } \\
& \text { (ic) }\end{array}$ & $76.0(1)$ & $21.0(.27)$ & $\begin{array}{l}33.3(.44) \\
32.8\end{array}$ & $\begin{array}{l}35.4(.46) \\
31.2\end{array}$ & $\begin{array}{l}1.06 \\
0.95\end{array}$ \\
\hline GK. H5593 (c) & 126.0 & $37.2(.29)$ & $56.0(.44)$ & $61.0(.46)$ & 1.09 \\
\hline (ic) & 117.0 & $34.3(.29)$ & $51.0(.43)$ & $52.0(.44)$ & 1.02 \\
\hline TA. 4 (deformed) & Ca 100 & Ca $30 \quad(.3)$ & $46.5(.46)$ & $44.0(.44)$ & 0.94 \\
\hline
\end{tabular}

Remarks.-Based on the observation of numerous specimens from the Interior Province of North America, including MonRow's syntypes, of Acanthoceras amphibolum and the holotype of $A$. hazzardi, from Texas, we are inclined to regard $A$. hazzardi as a mere variety of $A$. amphibolum. A slight difference that the upper ventrolateral tubercles disappear slightly earlier in the holotype of $A$. hazzardi than in the illustrated syntypes of A. amphibolum can be regarded as variation. In this respect the specimens from Hokkaido are rather closer to the latter. An incompletely preserved specimen, BM. 2399 (GRIMSDALE Collection), labelled as Acanthoceras cunningtoni, from the Cenomanian of Cherdstock, England, is probably another example of A. amphibolum.

Comparison.-Acanthoceras amphibolum MoRrow resembles Acanthoceras latum CRICK, 1907 (p. 195, pl. 12, fig. 2, 2a), from the Cenomanian of Zululand, South Africa. The distinction is in that the African species has much thicker whorl (with B./H. 1.17 in the holotype) and clearly more persistent ventral tubercles. Although CRICK ascribed $A$. latum to the group of $A$. cunningtoni, it is not referred to Euomphaloceras because it does not show multiplication of ventral tubercles nor constriction like depressions on the venter.

Occurrence.-The described specimens from Hokkaido came from loc. Ik 1051 and Ik 1102, sandstone bed in the main part of member IIb of the Mikasa Formation, Ikushumbets area.

A. amphibolum occurs abundantly as a zonal index at a level in the middle part of the Cenomanian sequence in the Western Interior Province of North America (see CoBBAN and REESIDE, 1952). The representative in Texas, called A. hazzadi, occurs in the Lewisville member of the Woodbine Formation (STEPHENSON, 1953).

In view of the presence of a probable example in the British Cenomanian, in addition to the above three regions, a widespread distribution of the species can be expected.

\section{Acanthoceras cornigerum CRICK}

Pl. 32, Fig. 1; Text-fig. 5

1907. Acanthoceras cornigerum CRICK, p. 207, pl.13, fig. 1.

1957. Acanthoceras cornigerum, MATSUMoto, SAITo and FUKADA, p. 18, textfig. 5 . 
Holotype.-BM. C. 18230, described and illustrated by CRICK, 1907 (p. 207, pl. 13, fig. 1).

Material.-GK. H5607 [=Ik. TA3], from loc. Ik 1102, Ikushumbets valley, central Hokkaido (collected by T. TAKAHASHI).

\section{Measurements.-}

\begin{tabular}{|c|c|c|c|c|c|}
\hline Specimen & Diameter & Umbilicus & Height & Breadth & B. $/ \mathrm{H}$ \\
\hline BM.C. $18230 \quad$ (c) & $69 \quad(1)$ & $21 . \quad(.30)$ & $30 \quad(.43)$ & $33 \quad(.48)$ & 1.10 \\
\hline (ic) & $63 \quad(1)$ & $21 \quad(.46)$ & $24 \quad(.38)$ & $26 \quad(.41)$ & 1.08 \\
\hline$(-1 / 2$ vol. $)(c)$ & $44.0(1)$ & $13.0(.29)$ & $19.0(.47)$ & $22.5(.51)$ & 1.18 \\
\hline GK.H 5607 & Ca 120 (1) & $42.8(.35)$ & $46.2(.38)$ & $55.2(.46)$ & 1.19 \\
\hline (c) (last septum & Ca 118 (1) & $37 \quad(.31)$ & $54 \quad(.45)$ & $61 \quad(.51)$ & 1.12 \\
\hline
\end{tabular}

(The dimentions of the holotype measured by MATsumoto may be slightly different from those by CRICK, 1907)

Descriptive remarks.-The specimen from Hokkaido is larger than the holotype. The former is probably an adult shell, with the last suture at the intercostal diameter of about $110 \mathrm{~mm}$., while the latter is wholly septate and somewhat eroded.

The whorl is somewhat broader than high and broadest in the lower part, or between the umbilical tubercles, being roughly trapezoid in section.

The outer whorl of Hokkaido specimen has widely separated, strong, rectiradiate ribs, which are provided with prominent tubercles at some distance above the umbilical margin and at the ventrolateral shoulder. On the last half whorl the ventrolateral tubercles become horns which are projected obliquely sideward and upward.

On the inner whorl the ribs are alternately long and short. They are not so strong nor so distant as those on the outer whorl, but those with umbilical tubercles are moderately strong. They are somewhat prorsiradiate and sometimes flexuous. The siphonal and upper and lower umbilical tubercles are

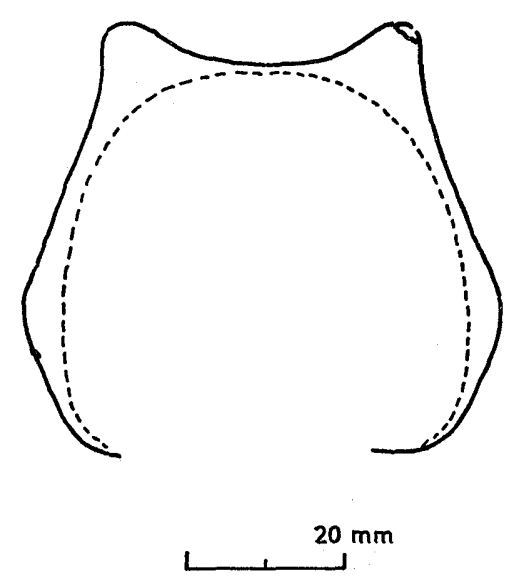

Fig. 5. Acanthoceras cornigerum CRICK. Costal whorl section of a specimen from Hokkaido, GK. H5607. (T. MAT. delin.) concealed by the embracing outer whorl and impressed on the internal surface of the latter. The umbilical tubercles are closer to the umbilical margin.

In all the above characters the Hokkaido specimen is very similar to and probably conspecific with the holotype from South Africa, although the distant ribs and prominent tubercles of the adult type appear at a smaller diameter in the holotype.

Acanthoceras cornigerum CRICK resembles Acanthoceras amphibolum 
Morrow, 1935 (emended above), in the horned and distantly costate outer whorl, but it is distinguished in its roughly trapezoid in stead of quardrate whorl-section and frequent intercalation of shorter ribs on the inner whorl.

Occurrence.-Loc. Ik 1102, on the northwestern wall of the valley of the Ikushumbets, in sandstone of member IIb (the same level as loc. Ik 1051) of the Mikasa Formation, central Hokkaido.

\section{Genus Euomphaloceras Spath, 1923}

Type-species.-Ammonites euomphalus SHARPE, 1855 (original designation).

Synonyms.-Cunningtoniceras CoLlignoN, 1937 (with type-species Ammonites cunningtoni SHARPE, 1855) ; Lotzeites WIEDMANN, 1959 (with type-species Acanthoceras aberrans Kossmat, 1895).

Generic characters.- The shell may attain to a fairly large size in the fullgrown stage. The whorl is rather evolute, encircling a deep umbilicus, and more or less depressed, with a broad venter and subquadrate to coronate cross section.

Prominent tubercles at or above the umbilical shoulder and at the ventrolateral shoulder are diagnostic. The ventrolateral tubercles are more or less spinose on the inner whorl and horn-like on the outer whorl. On the flank ribs are straight, over which the tubercles predominate; there may be intercalated shorter ribs, but they are normally infrequent and disappear on the outer whorl. On the broad venter of the young to middle growth-stages the ribs are multiplied, by branching at the ventrolateral tubercles and also by intercalation. On these minor ribs there are small siphonal tubercles, which are sooner or later weakened and finally disappear. In addition to them there are tubercles between the siphonal row and the ventrolateral ones. They are as numerous as the siphonal tubercles in some cases or less numerous in other cases on account of the state that a single clavate tubercle occurs in the place of two small ones of the intermediate (i.e. upper ventrolateral) row on the venter. Anyhow, the multiplication of ventral tuberculation is characteristic. In these young to middle growth-stages the multiplied ribs cross the venter transversely but sometimes with a slight projection; they may be periodically accompanied with constrictions; their prominence in relation to tubercles is variable, in other words the ventral ribs are perdominant over ventral tubercles or vice versa, depending on species or even on individuals. Sooner or later on the outer whorl the upper ventrolateral tubercles are amalgamated with the main, lower one, which, in turn, are enlarged into horns. In this stage the ventral ribs are lowered or even become obsolete.

The suture is fundamentally of Acanthoceras type, but its details may be considerably modified depending on species and on growth-stages. The saddle between $\mathrm{E}$ and $\mathrm{L}$ is massive and subsquarish in some species, subtrapezoid in some others, and even narrow and converging in others. L may vary in breadth and shape.

Remarks.-In addition to E. euomphalum (SHARPE), with which Acantho- 
ceras giltairei PERVINQUIÈRE, 1907, is a synonym, E. cunningtoni (SHARPE, 1855), E. meridionale (SToLICZKA, 1864) and E. lonsdalei (Adkins, 1928) are undoubtedly assigned to Euomphaloceras.

On the basis of the observation of a considerable number of specimens, we would generally agree with WRIGHT's (1963, p. 608) recent view in taking in this genus "little account of minor variations in the size and direction of the ventrolateral horns on the outer whorl or in the prominence of tubercles in relation to ribs on the venter in the middle growth-stages", although we would prefer to distinguish $E$. meridionale from $E$. cunningtoni.

Acanthoceras aberrans Kossmat, 1895, is referable to Euomphaloceras on account of prominence of the umbilical and ventrolateral tubercles and multiplication of ribbing (with reduced tubercles) on the venter of immature shells. It is more closely allied to $E$. euomphalum than to any species of Calycoceras. Therefore, Lotzeites WIEDMANN, 1959, established on $A$. aberrans as typespecies, is better included in Euomphaloceras.

Although we have not observed the original specimen, the holotype of "Calycoeras (Lotzeites) lotzei WIEDMANN, 1959 (p. 732, text-fig. 1, pl.2, figs. $1,2)$ is probably an immature shell of a Euomphaloceras, whose adult shell is not known. On the other hand, Acanthoceras bathyomphalum KossMAT, 1895 (p. 197 [101], pl. 25 [11], fig. 4a-d) is certainly assigned to Calycoceras. Its holotype is a small, probably immature shell. In our collection there is a larger example (Muramoto Coll. 16883, from Nishikatsura-zawa, Mikasa Sandstone on the western wing of the Ikushumbets anticline) of over $100 \mathrm{~mm}$. in diameter, which is essentially similar to the holotype. Its whorl is much depressed, with the proportion of about 1.5 between breadth to height, and an arched venter. It is ornamented with ribs of moderate intensity, fairly strong, umbilical and ventrolateral tubercles, and three rows of weaker ventral tubercles. The ventrolateral tubercles do not show horn-like exaggeration. Shorter ribs are branched at or intercalated near the umbilical tubercles as in other Calycoceras, but no branching occurs at the ventrolateral tubercles nor are there extra intercalates on the venter. Thus Calycoceras bathyomphalum is not related to Euomphaloceras aberrans.

It could be expected that Calycoceras might have lead to a form with hypernodosity and multiplied ventral ribbing, just as Acanthoceras gave rise to Euomphaloceras. But actually such a hypothetical phylogenetic series has not been confirmed. 'Acanthoceras' aberrans does not lie on such a line of descent. On the outer whorl of Calycoceras ventrolateral tubercles as well as the ventral ones are weakened and absorbed by the predominant ribs, and can have nothing to do with ventrolateral hypernodosity.

HANCOCK $(1959$, p. 250) preliminarily reported the existence of a species, from the middle part of the Cenomanian of France, which could be placed under a new subgenus representing an intermediate position between Acanthoceras and Euomphaloceras. His information is so brief that we cannot give comments on that species. Anyhow, it is probably certain that Euomphaloceras was derived from Acanthoceras through such species as Acanthoceras latum 
CRICK, 1907, and Acanthoceras evolutum SPATH, 1926.

Acanthoceras athabascense WARREN and STELECK, 1955 (p. 71, pl. 5, figs. 5, 6; pl. 7, figs. 1, 3, 4; pl. 8, figs. 1-3; pl.9, fig. 2), from the Cenomanian of Alberta, was regarded by Canadian palaeontologists (e.g. JELETZKY, 1968, p. 24) as being closely allied to Euomphaloceras cunningtoni or E. euomphalum, but it does not show the Euomphaloceras type multiplication of ventral ornaments. It resembles more closely, and possibly conspecific with, Acanthoceras amphibolum MORRow (redescribed above), although more or less different condition of preservation between the specimens of Canada and the United States gives us difficulty in concluding the identity.

In the previous paper (MATSUMото et al., 1957) several imperfectly preserved specimens from Hokkaido were described under Euomphaloceras cf. euomphalum and Euomphaloceras [Acanthoceras?] sp. indet. The former may be called in our present knowledge Euomphaloceras cf. cunningtoni. There is another specimen, GK. H5611 [=MURAмото Coll. 16200], which is referable to Euomphaloceras lonsdalei. Its large outer whorl is much deficient and its next inner whorl (about $80 \mathrm{~mm}$. in diameter across the intercostal part), has sideward produced ventrolateral horns and the ventral ornament of lonsdalei type (see remarks in page 275), but the siphonal tubercles are somewhat irregular in intensity and shape. The specimen came from the sandstone bed in the main part of unit IIb of the Mikasa Formation, exposed on a small stream (Suidono-sawa) hanging on the right wall of the main valley of the Ikushumbets.

Besides these imperfect specimens, there are better preserved ones in our present collection which are identified with $E$. meridionale and another interesting one which represents a new species. The last one is atypical and peculiar in having numerous secondary ribs, but is better ascribed to Euomphaloceras than to any other genera.

Euomphaloceras meridionale (STOLICZKA)

Pl. 33, Figs. 1-2; Pl. 34, Fig. 1; Text-fig. 6

1864. Ammonites meridionalis SToLICZKA, p. 76, pl. 41, fig. 1a-c.

1897. Acanthoceras meridionale, Kossmat, p. 20 [127].

1907. Acanthoceras meridionale var. africana Penvinquière, p.278, pl.15, figs. 2a, b, 3, 4a, b; text-fig. 106.

1907. Acanthoceras meridionale var. tuberculata PERvinquière, p. 28, pl.15, figs. $5 a, b, 6 a, b$.

1963. Euomphaloceras cunningtoni meridionale, WRIGHT, p. 608 , pl. 89 , fig. 1.

Lectotype.-GSI. 175, figured specimen of SToLICZKA (1864, pl.41, fig. 1, la-c), from Odium, Middle Utatur Group, southern India, here designated. This is wholly septate. The largest syntype, measured by SToLICzKA as $230 \mathrm{~mm}$. in diameter, seems to be missing.

Material.-GK. H5592 (Coll. M. WADA, 1958, the then school-boy of the Mikasa High School), GK. H5606 (Coll. T. TAKAHASHI, TA. 2), GK. H5612 
[=Muramoto 12456, collected by K. Muramoto], and GK. H5613 [Coll. T. TAKAHASHI] are the specimens from Hokkaido.

Specific characters.-The shell is large, about or somewhat over $200 \mathrm{~mm}$. in diameter at the full-grown stage.

The whorl is rather evolute and shows a moderate rate of growth, encircling an umbilicus of moderate size (about 30 percent of diameter). It is much depressed, with proportion of $10: 14.5( \pm 2)$ between breadth to height and is subrectangular in intercostal section, having a very broad venter, subparalled flanks, a nearly vertical, high umbilical wall, and abruptly rounded ventrolateral and umbilical shoulders.
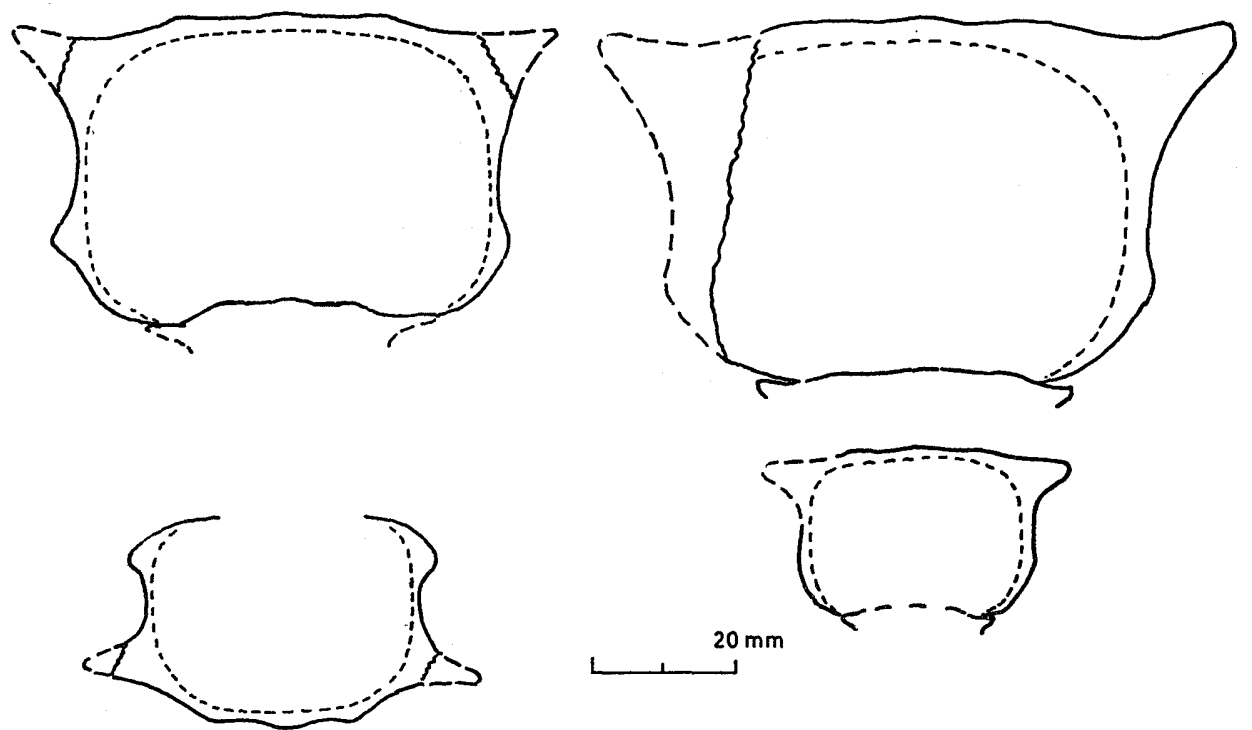

Fig. 6. Euomphaloceras meridionale (STouICZKA). Costal whorl-sections. Left: Lectotype, GSI. 175, from southern India, right: a specimen from Hokkaido, GK. H5612. (T. MAT. delin.)

The inner whorls are ornamented with distant major ribs, which are provided with bullate umbilical and spinose ventrolateral tubercles, and multiplied ventral ribs which have smaller tubercles in three rows. Constrictions are discernible along some of the ventral ribs. The multiplication of ribbing on the venter is resulted from the bifurcation of a major ribs at the ventrolateral tubercle and also from the intercalation of a rib between the major ones. The anterior one of the bifurcated ribs may show a gentle forward curve; other ribs straightly cross the venter. The umbilical tubercles are most elevated at a point somewhat above the umbilical margin, increasing their elevation as the shell grows. The ventrolateral spines are stretched sideward, leaning against the umbilical wall of the outer whorl. The ventral tubercles are rounded or elongated transversely. They are twice or three time as numerous as the ventrolateral ones. 
On the outer whorl the major ribs are very widely separated and the tubercles above the umbilical shoulder and at the ventrolateral periphery are very prominent. Especially the ventrolateral tubercles form horns which are thick and rounded at the base and remarkably stretched sideward (i.e. perpendicular to the flank) and may be curved slightly upward at the apex. The ventral ribs and tubercles are sooner or later weakened and finally disappear.

The suture is of Acanthoceras type, with a massive and large first lateral saddle. The lateral lobe (L) is asymmetrically bipartite, with narrow branches, but its stem is not so narrowed.

Variation.-As the available specimens are not sufficiently numerous, the extent of variation can be only roughly given. In addition to a certain varibility in the proportion between whorl breadth and height (i.e. 1.5 \pm 0.1 ), the relative predominance between ribs and tubercles on the venter is variable, as exemplified by PERVINQUiÈRE's (1907) varieties africana and tuberculata. There is also variation in the density, intensity and persistency of the ventral ornaments.

In the lectotype from India, which is a shell of middle growth-stage, the ventral ribs and tubercles are of moderate density, intensity and persistency.

Some of the Tunisian specimens (Pervinquière, 1907, pl. 15, figs. 3, 4) seem to have more persistent and stronger ventral ribs than the Indian lectotype, although the intercalated ribs disappear earlier than the major ones. On the other hand, in the available specimens from Hokkaido the ventral ribs, as well as the ventral minor tubercles, are weaker and disappear earlier than in the Indian lectotype, and, accordingly, the venter looks almost smoothish on the entire outer whorl, from the late part of the septate stage up to the apertural end. Furthermore, in both GK. H5612 and H5613 the ventral minor tubercles of the early and middle growth-stages are bullate (i.e. elongated transversely along the ribs) instead of clavate or rounded. Should these features constantly occur in the Japanese specimens, they would deserve subspecific distinction. As the available material is insufficient, we refrain from establishing a new subspecies at this moment. For the same reason, whether the varieties africana and tuberculata deserve subspecific ranking or not is not decided here.

\begin{tabular}{|c|c|c|c|c|c|c|c|c|}
\hline \multicolumn{9}{|l|}{ Measurements.- } \\
\hline Specimen & Diameter & \multicolumn{2}{|c|}{ Umbilicus } & \multicolumn{2}{|c|}{ Height } & \multicolumn{2}{|c|}{ Breadth } & B./I \\
\hline GSI. 175 (ic) & $97.0(1)$ & \multicolumn{2}{|c|}{$31.0(.32)$} & \multicolumn{2}{|c|}{$39.2(.40)$} & \multicolumn{2}{|c|}{$56.0(.58)$} & 1.42 \\
\hline$\left(-20^{\circ}\right)(\mathrm{c})$ (excl. spine) & $98.5(1)$ & \multicolumn{2}{|c|}{$29.0(.29)$} & \multicolumn{2}{|c|}{$42.0(.41)$} & \multicolumn{2}{|c|}{$60.0(.61)$} & 1.43 \\
\hline GK. H5592 (c) & $223.0(1)$ & \multicolumn{2}{|c|}{$66.0(.29)$} & \multicolumn{2}{|c|}{$99.0(.44)$} & \multicolumn{2}{|c|}{$142.0(.63)$} & 1.43 \\
\hline$\left(-20^{\circ}\right)(\mathrm{ic})$ & $195.0(1)$ & \multicolumn{2}{|c|}{$57.0(.29)$} & \multicolumn{2}{|c|}{$82.5(.42)$} & \multicolumn{2}{|c|}{$101.0(.52)$} & 1.36 \\
\hline GK. H5612 (c) (excl. spine) & - & \multicolumn{2}{|c|}{ - } & \multicolumn{2}{|c|}{51.0} & \multicolumn{2}{|c|}{76.0} & 1.49 \\
\hline$\left(-320^{\circ}\right)(\mathrm{c})$ (excl. spine) & $56.7(1)$ & \multicolumn{2}{|c|}{$16.8(.29)$} & \multicolumn{2}{|c|}{$24.5(.43)$} & \multicolumn{2}{|c|}{$36.0(.51)$} & 1.47 \\
\hline GK. H5613 (c) (excl. spine) & $20.5(1)$ & \multicolumn{2}{|c|}{$5.8(.28)$} & \multicolumn{2}{|c|}{$8.0(.39)$} & \multicolumn{2}{|c|}{$13.2(.64)$} & 1.65 \\
\hline \multicolumn{9}{|l|}{ For comparison } \\
\hline BM. 88704 (last septum) (ic) & $118 \quad(1)$ & 38 & $(.31)$ & 50 & $(.42)$ & 59 & $(.50)$ & 1.18 \\
\hline USNM. 105970 (c) & $125 \quad(1)$ & 40 & (.32) & 50 & $(.40)$ & 63 & $(.50)$ & 1.26 \\
\hline BEG. 2410 (inner whorl) (c) & 80 (1) & 22 & $(.27)$ & 34 & $(.42)$ & 43 & (.54) & 1.26 \\
\hline "A. c. cornuta" & 154 (1) & 56 & (.36) & 59 & (.38) & 84 & $(.55)$ & 1.42 \\
\hline "E. c. pervinquieri" & $87 \quad(1)$ & 29 & (.33) & 36 & (.41) & 51 & (.59) & 1.4 \\
\hline
\end{tabular}




$\begin{array}{llllllllll}\text { “A. m. africana", } & 40 & (1) & 12 & (.30) & 18 & (.45) & 26 & (.64) & 1.44 \\ \text { "A. m. tuberculata" } & 37 & (1) & 11 & (.30) & 17 & (.46) & 22 & (.60) & 1.30 \\ \text { "A. c." PERVINQUIÈRE } & 67 & (1) & 22 & (.32) & 26 & (.39) & 38 & (.57) & 1.46\end{array}$

BM. 88704: holotype of Ammonites cunningtoni SHARPE, 1855.

USNM. 105970: holotype of Acanthoceras ? eulessanum STEPHENson, 1953 BEG. 2410: holotype of Acanthoceras lonsdalei ADKINS, 1928.

“A. cunningtoni” Perrvinquière, 1907, pl. 15, fig. 1a-c.

Comparison.-We generally agree with WRIGHT (1963) in allowing considerable variability and in refraining from erecting too many species in Euomphaloceras, but as regards the way of specific distinction we are not necessarily of the same opinion with him. We think it better to distinguish $E$. meridionale (STOLICZKA) from $E$. cunningtoni (SHARPE, 1855) specifically rather than subspecifically. In India, northern Australia and other areas they occur in the same province. In other words they do not show a clear geographic separation. They show, however, a considerable difference in morphological features as explained below, which must be related to some ecological difference and seems to deserve specific separation. In the early to middle growth stages of $E$. meridionale each major rib is divided at the ventrolateral tubercle and a minor or shorter rib is normally alternated with the major ones, although there is occasionally no intercalation. Thus multiplication of ribbing is distinct on the venter. On each of the ventral ribs there are three, nearly equally small tubercles, of which one is on the siphonal line. In $E$. cunningtoni the siphonal tubercles are two to three time as numerous as the ventrolateral tubercles, but corresponding to two of these siphonal tubercles there is on either side a clavate tubercle which is somewhat stronger than the siphonal one but weaker than the ventrolateral one. In this connexion the branching of the major rib at the ventrolateral tubercle is not so distinct as in $E$. meridionale.

In all the examined specimens of $E$. meridionale the ventrolateral tubercles are stretched mainly sideward, being nearly perpendicular to the flank, while in the holotype and other typical specimens of $E$. cunningtoni they are extended obliquely upward and sideward, forming a ventral valley in the costal section (see MAтsumoto et al., 1957, text-fig. 13).

On the average $E$. meridionale has much broader whorl than $E$. cunningtoni. As is indicated in the measurements, the proportion of whorl-breadth to height in the lectotype and other examples of $E$. meridionale is much larger (1.4-1.6) than that in the holotype of $E$. cunningtoni $(\sim 1.2)$ and the holotype of Acanthoceras ? eulessanum STEPHENson (1953, pl. 47, fig. 5, pl.48, figs. 3,4), a synonym of $E$. cunningtoni. The proportion is, however, variable and the variations of the two species in this respect is overlapping to some extent.

Euomphaloceras lonsdalei (ADKINs) (1928, p. 244, pl. 26, fig. 5, pl.27, fig. 3) seems to have been misunderstood. Its holotype, BEG. 2410, is nearly as broadly whorled as, or even somewhat broader than, the typical form of $E$. cunningtoni, but is not so thick as typical $E$. meridionale. In the ventral 
ornamentation of the early to middle growth-stages $E$. lonsdalei shows somewhat intermediate feature between $E$. cunningtoni and $E$. meridionale. In the early stage of BEG. 2410, up to a diameter of about $60 \mathrm{~mm}$., one of the two ventral ribs which are divided from each major rib at the ventrolateral tubercle is somewhat broader than the other and also than the intercalated rib and the upper ventrolateral tubercle on the former is stronger and more elongated (i.e. clavate) than other ventral tubercles. The siphonal tubercles are three times as numerous as the ventrolateral ones and of subequal intensity. In the middle growth-stages of 60 to $80 \mathrm{~mm}$. diameters the branching of the rib becomes indistinct and a single, clavate upper ventrolateral tubercle corresponds to each large, lower one and to each two of the siphonal tubercles, showing the cunningtoni type ornamentation. In the last stage ventral ornaments are weakened, and the upper ventrolateral clavus is united into a ventrolateral horn. It is furthermore noticed that in the holotype of $E$. lonsdalei the major ribs are somewhat more numerous than in $E$. meridionale and $E$. cunningtoni, being 13 or 14 as compared with 10 or 11 in the latter, and the ventral ribbing is more crowded. The apex of the ventrolateral tubercle is broken in the holotype, but seems to show a sideward rather than upward direction. Although there could be variation in these features, we should not neglect the facts observed in the holotype.

On the basis of the above observation of the holotype of $E$. lonsdalei, it can be considered that some specimens previously referred to $E$. cunningtoni may be better transferred to E. lonsdalei. For example, one of PeRVINQuiere's specimen (1907, pl. 15, fig. 1) and E. euomphalum pervinquieri CoLLIGNON (1964, p. 145 , pl. 373 , fig. 1) seem to be referable to $E$. lonsdalei, but without seeing the specimens it is difficult to give the final decision.

Anyhow, the distinction between $E$. meridionale and E. cunningtoni is clearer than that between $E$. lonsdalei and $E$. cunningtoni.

Occurrence.-The Hokkaido specimens of $E$. meridionale were obtained at loc. Ik 1052 and nearby localities from a sandstone bed in the lower part of member IIb of the Mikasa Formation, above the bed with Mantelliceras japonicum and below the bed with Calycoceras orientale, in the sequence of the Ikushumbets valley. Also loc. Ik 1103 of the same valley, on the western wing of the Ikushumbets anticline.

The lectotype is recorded to have come from the Middle Utatur Group, Odium, southern India, without information of more precise horizon. PERvinquikere's specimens are from the Cenomanian of Mrhila, Bireno, and Sidi bou Goubrine, Tunisia. According to PeRvinquière the same species is said to have been found in France, although we cannot confirm the identification without seeing the specimens. WRIGHT (1963) reported the occurrence of an example in beach pebbles at Moonkinu, on the sough-east coast of Bathurst Island, northern Australia. 
Euomphaloceras asura Matsumoto and MuRAmoto, sp. nov. Pl. 35, Fig. 1; Pl. 36, Fig. 1; Text-fig. 7

Etymology.-Asura (Sanskrit) a deity in Buddhism, who likes to fight. The highly ornamented form of this ammonite reminds us of a sculpture of Asura [Ashura in Japanese].

Material.-GK. H5602, from loc. T1165p, Saku area, Teshio Province (collected by MATSUMOTo and MURAMoTo). No other specimen is available at present.

Specific characters.-The shell is large and widely umbilicate, consisting of moderately growing evolute whorls. The whorl is much depressed, with proportion of about 1.4 between breadth and height in intercostal parts, coronate in section, having a steeply inclined umbilical wall without angular shoulder, somewhat diverging flanks, subangular ventrolateral shoulders and a flat and broad venter.

Distant major ribs, nine per whorl, are provided with strong ventrolateral horns and bullate umbilical tubercles which are pointed at a considerable distance from the umbilical margin. On the inner whorl, preceding to the last one, the ventrolateral horns are stretched obliquely sideward and upward, leaning against the steeply inclined umbilical wall of the outer whorl. On the outer whorl itself the umbilical tubercles are shifted still higher up and tend to be united with the ventrolateral horns, which, in turn, are much enlarged as the shell grows and finally in the last part the two ventrolaeral horns are modified to two high flares, which are vertically elevated to form steep transverse walls, with a narrow gape between them at the middle of the venter.

In addition to the major ribs and tubercles there are minor, narrower ribs on the interspaces and also on the major ones, some of which form loops at the ventrolateral tubercles. They occur on the last two whorls and are three times (earlier) to five times (later) as numerous as the major ones. Some of the interspaces between the minor ribs are deeper than others, showing a constriction like aspect. The minor ribs are distinct and persistent on the flank, but weak and become almost obsolete on the venter. On the flank the ribs are nearly rectiradiate, but some are slightly rursiradiate. On the venter they run transversely, without showing notable projection. As the minor ribs are weak on the venter, the ventral, multiplied, minor tubercles are scarcely discernible on the outer whorl. Probably they have disappeared in the middle growth-stage, although there are faint traces of them on the early part of the outer

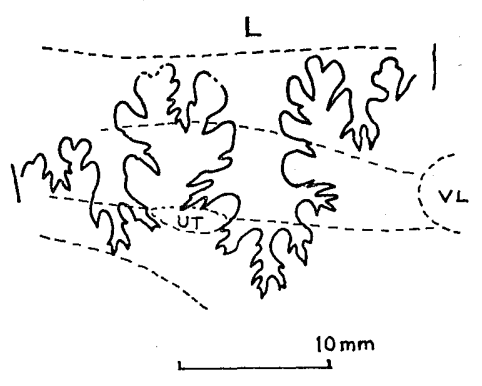

Fig. 7. Euomphaloceras asura Matsumoto and Muramoto, sp. nov. Part of the external suture of the holotype, GK. H5602. Ventral part is not shown. Dotted lines indicate position of the summit of ribs and the base of tubercles (UT: umbilical tubercles, VL: ventrolateral tubercle).

(T. MAT. delin.) 
whorl.

The suture is generally of Acanthoceras pattern. The first lateral saddle is large, massive, and paralled sided. The lateral lobe is comparatively narrow. The last suture is at an intercostal diameter of about $120 \mathrm{~mm}$. The bodychamber occupies about a half whorl, which is slightly reduced in breadth and height in the last part.

\begin{tabular}{|c|c|c|c|c|c|}
\hline \multicolumn{2}{|c|}{ Measurements of holotype.- } & \multirow[b]{2}{*}{ Umbilicus } & \multirow[b]{2}{*}{ Height } & \multirow[b]{2}{*}{ Breadth } & \multirow[b]{2}{*}{ B./H. } \\
\hline Position & Diameter & & & & \\
\hline Last part (ic) & $182(1)$ & $79(.43)$ & $61(.34)$ & $73(.40)$ & 1.2 \\
\hline$-90^{\circ}$ (c) (excl. horn) & $160(1)$ & $64(.40)$ & $64(.40)$ & $92(.57)$ & 1.4 \\
\hline$-180^{\circ}$ (ic) & Ca. $116(1)$ & $52(.44)$ & $42(.36)$ & $60(.52)$ & 1.4 \\
\hline$-330^{\circ}$ (c) & & & 32 & 46 & 1.4 \\
\hline
\end{tabular}

Comparison.-The present species is somewhat similar to Euomphaloceras aberrans (Kossmat) (1897, p. 202 [106], pl.24[10], fig. 4a-c), from the Middle Utatur Group of southern India, in the coronate whorl-section, spinose ventrolateral tubercles, presence of minor ribs between the tuberculated ribs on the flank as well as on the venter, and earlier disappearance of ventral tubercles. It is, however, distinguished from that species in its more distant, less numerous, major ribs, more numerous minor ribs, which are distinct on the flank and weaker on the venter, less arched, i.e., flatter venter and different pattern of suture, with more squarish first lateral saddle and much narrower lateral lobe. Holotype of $E$. aberrans is small and probably immature. How the ornamentation would change on the outer whorl of that Indian species is not known.

Anyhow, in the persistency of the minor ribs on the flank, earlier disappearance of ventral tubercles, and flared ventrolateral tubercles at the last stage, $E$. asura is considerably different from the better known species of Eomphaloceras, such as E. euomphalum, E. cunningtoni and E. meridionale, being atypical species of the genus.

The flaring of the ventrolateral tubercles reminds us of a similar feature in Dunveganoceras WARREN and STELCK, 1940, but in other respects, such as the highly depressed whorl, much predominant ventrolateral tubercles, and multiplication of minor ribbing, the species cannot be assigned to that genus.

Occurrence.-Loc. T1165p, Saku-gakko-no-sawa, Saku-Abeshinai area, Teshio Province, northwestern Hokkaido. This is a rolled (or fallen) block probably derived from unit IIb-c (see map of Matsumoto, 1942, pl. 10) and contains Anagaudryceras cf. sacya (FORBES), Zelandites sp. and Inoceramus ef. pennatulus PERGAMENT, in addition to Euomphaloceras asura. Unit IIb-c at this locality is regarded to belong to the highest part of the Cenomanian in the sequence of the Saku-Abeshinai area. The conformably overlying unit IIc contains, among others, Fagesia thevestensis (PERON), a Lower Turonian index.

Genus Kanabiceras REESIDE and WEYMOUTH, 1931

Type-species.-Acanthoceras (?) kanabense STANTON, 1894=Scaphites (?) septemseriatus CRAGIN, 1893. 
Generic characters.-Rather small and evolute shells, consisting of depressed whorls. Distant major ribs are more or less prorsiradiate, provided with tubercles at the umbilical shoulder and spinose ones at the ventrolateral shoulder. Minor ribs are multiplied on the venter by branching and intercalation. The ventral tubercles are also multiplied. As least in young to middle growth-stages the venter has periodic constrictions usually along the extension of the major ribs and three rows of tubercles, of which the siphonal ones are aligned on a low keel like elevation and the paired ones are oblique. Sutures are of Acanthoceras type.

Comparison and affinity.-In shell-form and ornamentation Kanabiceras is very close to Euomphaloceras, but is distinguished in its smaller size and in that in certain growth-stages the siphonal tubercles form a nodose keel and the paired ventral tubercles are obliquely arranged along the projected curvature of the ribs. This distinction may be obscured on the whorl of the late growthstage, in which ribs are prorsiradiate on the flanks in Kanabiceras.

For the reason of morphological resemblance and the stratigraphic occurrence Kanabiceras is regarded as a descendant of Euomphaloceras.

\section{Kanabiceras septemseriatum (CRAGIN) \\ Pl. 37, Figs. 1-3}

1893. Scaphites (?) septem-seriatus CRAGIN, p. 240.

1894. Acanthoceras (?) kanabense StAnton, p. 181, pl. 36, figs. 6-8.

1927. Acanthoceras kanabense, Moreman, p. 95, pl.13, fig. 5.

1931. Kanabiceras kanabense, REESIDE and WeYMouth, p. 11.

1942. Neocardioceras septemseriatum, Moreman, p. 213, pl.33, figs.11, 12; text-fig. $2 f$.

1952. Lyelliceras stanislausense ANDERSON, p. 247, pl.8, fig. 5, 5a.

1959. Kanabiceras septemseriatum, Matsumoto, p.99, pl. 24, fig. 1a-c; textfigs. 52, 53 .

Holotype.-CrAGIN's original specimen in the collection of BEG., University of Texas, which came from the Eagle Ford Formation of Dallas County, Keenan's Crossing of Trinity River, Texas. Its plaster cast (GK. H9137) is kept in Kyushu University.

Material.-The specimens from Hokkaido are GK. H5601, from loc. Ik $987 \mathrm{f}$ (T. Matsumoto Coll.), GK. H5614, from loc. Ik 1038 (T. Muramoto Coll.), and GK. H5562, from a nearby locality (T. TAKAHASHI Coll.). A fragmentary specimen, GT. I-3355, from loc. T852r (T. Matsumoto Coll.) may be referred to this species. There are some more examples in our private collections.

The specimens from America which one of us (T. MAtsumoto, 1959) studied are brought into comparison.

\begin{tabular}{lcclll}
\multicolumn{2}{c}{ Measurements.- } & & & & \\
Specimen & Diameter & Umbilicus & Height & Breadth & B./H. \\
GK. H5601 & $28.3(1)$ & $10.4(.36)$ & $11.0(.39)$ & $16.4(.58)$ & 1.48 \\
GK. H5614 & $73.0(1)$ & $26.8(.36)$ & $26.0(.35)$ & $18 \times 2(.49)$ & 1.39 \\
$\left(-190^{\circ}\right)($ c) & - & - & 15.0 & 21.5 & 1.43 \\
GK. H5562 & - & - & Ca. 16 & 25 & 1.5
\end{tabular}


Descriptive remarks.-The specific diagnosis, variation, and comparison with other species were given at length on the previous occasion (MATsumoto, 1959, pp. 99-102). There is essentially no need of revision for that description*.

Of the three specimens from Hokkaido, GK. H5601, which is small and probably immature, shows most typically the diagnositic characters of $K$. septemseriatum. Namely, evolute and depressed whorls, with inflated flanks and a broadly arched venter, major lateral ribs with umbilical tubercles and ventrolateral spinose tubercles, and minor, multiple, somewhat projected ventral ribs, which are provided with obliquely bullate tubercles on either side of the siphonal row of tubercles which, in turn, are aligned on a low, keel-like elevation. Some of the minor ribs may extend down to the flank, forming occasional intercalates between the major ribs on the flank.

Two other, larger specimens, GK. H5562 and GK. H5614, do not show such a notable projection of ventral ribs as in the above described small one, and accordingly the paired ventral tubercles are not necessarily obliquely elongated, but the ribs between the umbilical and ventrolateral tubercles are remarkably projected and the long ventrolateral spines are stretched forward in lateral view and obliquely upward and sideward in back or frontal view. On the fragmentary whorl of GK. H5562 and on the main part of the outer whorl of GK. H5614 the siphonal keel like elevation persists, but on the last part of the latter specimen it is lost and the siphonal tubercles are interrupted as on the inner whorl of normal Acanthoceras or that of Euomphaloceras.

The holotype and some other specimens, including GK. H5601 and H5614, have a few minor ribs even on the flank, of which some are purely intercalatory and others may form a loop at the ventrolateral tubercle. In this feature and other characters $K$. septemseriatum is fairly close to the inner whorl of Euomphaloceras asura (described above), although the prorsiradiate ribbing enables us to distinguish the former from the latter even in lateral view.

Occurrence.-Loc. Ik 987f, rock floor of the main stream of the Ikushumbets; loc. Ik 1038, cliff on the right bank of the same place, and another locality in a small tributary, Suido-no-sawa. All belong to a layer of siltstone at the top of unit IIc, middle member of the Mikasa Formation, central Hokkaido. A fragmentary whorl, GT. I-3355, which can be called Kanabiceras cf. septemseriatum, came from loc. T 852r, member IIc-d $(\beta)$ of Chirashinai, a tributary of the Teshio, northwest Hokkaido.

The holotype is recorded to have come from the Britton member, Eagle Ford Formation, Lower Turonian, Texas.

Subfamily Mammitinae HYATT, 1900

Genus Sumitomoceras Matsumoto, nov.

Etymology.-Dedicated to the Sumitomo Coal Mining Company, who have

* There are, however, misprints. Read $K$. septemseriatum for $K$. kanabense in lines 23 and 29 of page 101 and lines 7 and 6 of p. 102. 
provided fascilities for the study.

Type-species.-Sumitomoceras faustum Matsumoto and Muramoto sp. nov. (described below).

Generic characters.-The shell of this genus is rather small, discoidal, and fairly widely umbilicate, with a little involution. Its whorl is more or less compressed, with nearly parallel flanks and an arched venter.

Ribs are of unequal length, some of which are branched at the umbilical tubercles and others intercalated. The immature shell is provided with umbilical tubercles at the end of the long ribs and also lower and upper ventrolateral tubercles on each rib. In addition to them small siphonal tubercles are discernible in the early immature stage, but they soon disappear. In the middle and late growth stages the ventrolateral tubercles are weakened and then disappear, while the ribs are numerous, show a gentle projection at the ventrolateral shoulder, and distinctly run across the venter without interruption. The interspaces behind some of the long ribs may be somewhat deeper than others and can be called shallow constrictions.

Sutures are fundamentally of Acanthoceras type, the saddle between $\mathrm{E}$ and $\mathrm{L}$ is bifid, squarish and parallel sided; $\mathrm{L}$ is fairly deep, narrow, and asymmetrically bifid at the bottom.

Remarks.-In addition to the type-species, Ammonites ushas SToLICZKA, 1864, is assignable to Sumitomoceras. Acanthoceras amudariense ARCHANGUELSKY, 1916 (excluding "var. horridum"), may also be referred to Sumitomoceras rather than to Watinoceras.

Comparison and affinity.-The immature shell of Sumitomoceras is very similar to that of Watinoceras WARREN, 1930, in many respects. In the middle to late growth-stages of Sumitomoceras, the ventrolateral tubercles are weakened and then completely lost, while the ribs are distinct and cross the venter transverselly. In the corresponding stages of Watinoceras the ventrolateral tubercles persist and there is a ventral depression between the rows of upper ventrolateral tubercles. As far as the type-species are concerned, the suture of Watinoceras is simpler, having broader saddles, shallower lobes and shallower incisions than that of Sumitomoceras.

In connexion with the relation between the two genera, remarks should be given on Watinoceras itself. Watinoceras was introduced to accomodate a single species, $W$. reesidei WARREN, 1930, from the Lower Turonian of the Western Interior province of Canada. WARREN's (1930, p. 66) description of the generic diagnosis is as follows:

"Discoidal forms, slightly involute and laterally compressed. Costae generally alternating in length, not crossing the venter, developing two rows of nodes on each side of the venter and occasional nodes on the umbilical border in gerontic stages".

If this diagnosis is maintained, the distinction between Watinoceras and Sumitomoceras is very clear. Although WARREN included no species other than W. reesidei, Acanthoceras coloradoense HENDERson, 1908 (p. 259, pl. 13, fig. 10), from the Lower Turonian of Colorado, Acanthoceras horridum ARCHANGUELSKY 
1916 (p. 49, pl. 8, figs. 8-10, 14-15), (which was originally proposed as a variety of $A$. amudariense but is distinct enough for specific separation), from the Lower Turonian of Turkestan, and probably also a species incorrectly referred to "Schloenbachia gracillima Kossmat" by Petrascheck (1902, p. 153 [23], pl. 9 [3], fig. 3a, b), from the Labiatus-Pläner (Lower Turonian) of Germany, are assigned to Watinoceras.

The illustrated specimens, including the holotype, of Watinoceras reesidei WARREN (1930, p. 67, pl. 3, fig. 2; pl.4, figs.9-12) are small. Accordingly there might remain a doubt whether they were actually mature or not. WARREN mentioned the existence of larger specimens which have a body-chamber. Therefore I would rely on his description, unless some objections would occur in subsequent collections.

In the meanwhile WRIGHT (1957) gave a generic diagnosis of Watinoceras somewhat more comprehensively, to accomodate Acanthoceras amudariense ARchanguelsky, 1916, from Turkestan. To cite from him (Wright, 1957, p.L 416) "Early whorls compressed, finely ribbed, with inner and outer ventrolateral and siphonal tubercles as in Neocardioceras, but siphonal row soon lost; later, venter may be concave between rows of ventrolateral clavi or rounded, with ribs passing over in chevrons; ornament usually coarsens with age."

As is described below, the immature shells, up to a diameter of about $30 \mathrm{~mm}$., of the type-species of Sumitomoceras resembles the illustrated specimens of A. amudariense, but the ribs of the former does not show such ventral chevrons as those of the latter. Whether $A$. amudariense is referred to Sumitomoceras or Watinoceras may depend on authors' opinion. I am rather inclined to ascribe A. amudariense to Sumitomoceras, because in its later growth-stages the ventrolateral tubercles are weakened and the ribs pass over the venter.

I agree with WRIGHT (1957) in considering the derivation of Watinoceras from Neocardioceras. Similarly but along another line of descent Sumitoceras probably came from Neocardioceras, although in the Japanese sequence examples of the latter has not been found and only those of Protacanthoceras, the immediate ancestor of Neocardioceras, have been confirmed. Thus, Sumitomoceras and Watinoceras are in a sisterhood relationship, deviating considerably from each other.

The young shells of Sumitomoceras and Watinoceras are somewhat similar to Mantelliceras. Watinoceras was once placed under Mantelliceratinae on that account. But the resemblance is not genetical, because the siphonal row of tubercles discernible in early young stage, among other features, tells the close affinity with Neocardioceras of the Acanthoceratinae. For this reason and for its close relation with Mammites, Watinoceras has been correctly transferred to the Mammitinae by WRIGHT (1957). Although Sumitomoceras shows characters considerably different from Mammites, it can be assigned to the same subfamily, because of its close relationship with Watinoceras.

It is interesting to note that the immature shell of Sumitomoceras is somewhat similar to Holcodiscoides and the adult shell is remarkably so to 
certain species of Kossmaticeras (e.g. K. theobaldianum) of the Kossmaticeratidae and to Mesopuzosia or Kitchinites of the Puzosiidae. This is an example of homoeomorphy which suggests a similarity in mode of life.

Occurrence.-The type-species of Sumitomoceras occurs in the Lower Turonian of Japan, as does S. amudariense in the Lower Turonian of Turkestan. The age of $S$. ushas in India is not precisely known.

Sumitomoceras faustum MATSUмото and MuRAmoto, sp. nov. Pl. 38, Figs. 1-4; Text-fig. 8

Etymology.-Faustum: bringing good luck.

Material.-Holotype: GK. H5595, from loc. Ik 1038 Ikushumbets valley. Paratypes: GK. H5561, H5600, H5615, H5616, and H5617, from the type-locality. The holotype is an adult shell. Paratypes are of various growth-stages. All the specimens were collected by T. MURAmoto, except for GK. H5561 by T. TAKaHASHI, in the field work conducted by T. Matsumoto.

Specific characters.-The early immature shell, less than $15 \mathrm{~mm}$. or so in diameter, as represented by GK. H5617 and H5616, is moderately involute, about a half (in height) of the inner whorl being embraced by the outer, consisting of moderately growing discoidal whorl, which is somewhat higher than broad, flattened on sides and fairly narrowly arched on the venter. There are distant, small, rounded tubercles at the umbilical shoulder, seven or so per whorl, from which spring long, prorsiradiate ribs, alternating with shorter ones. Ribs are projected on the ventrolateral shoulder where they have two tubercles, lower and upper. Between the upper ventrolateral tubercles on the venter the ribs are weakened and there is a siphonal row of weak, clavate tubercles, which sooner or later disappear.

In the late immature shell, of diameters between $15 \mathrm{~mm}$. to 25 or $30 \mathrm{~mm}$, as exemplified by GK. H5600 and H5615, and also the inner whorls of GK. H5561 and H5595, the whorl is discoidal, less involute and somewhat compressed, with flat and parallel flanks, perpendicular but low umbilical walls, sloping ventrolateral shoulders and a gently arched or nearly flat venter. There are numerous ribs of unequal length, some of which spring in pairs from the umbilical tubercles, and some others intercalated. They are moderately or slightly sigmoidal, regularly projected on the ventrolateral shoulder, and cross the venter transversely, although with slight weakening. There are no siphonal tubercles. Every rib has small but distinct, two ventrolateral tubercles, lower and upper. The tubercles at the umbilical shoulder, near the end of the long ribs, are small but prominent in this stage, being stronger than the ventrolateral ones, slightly stretched sideward, and more numerous than in the earlier stage, 12 or so per whorl. The ribs are somewhat weakened above the umbilical tubercles on the lower part of the flank.

In the probably adult shell, i.e. in the late part of the septate whorl and in the body-whorl, of diameters from about $30 \mathrm{~mm}$. to about $60 \mathrm{~mm}$. or more, the umbilicus is of moderate size and the involution is small, concealing the 


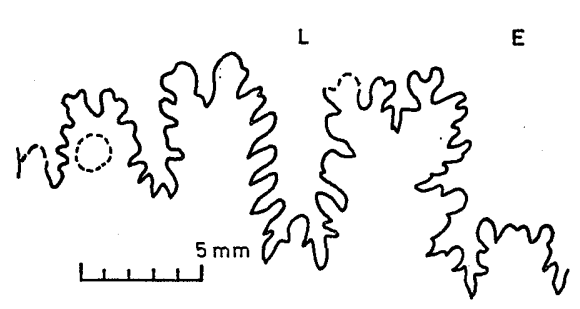

Fig. 8. Sumitomoceras faustum MATsUMоTо and Muramoto, sp. nov. External suture of a paratype, GK. H5561, at whorl-height $=17 \mathrm{~mm}$.

(T. MAT. delin.)

venter of the inner whorl down to the row of lower ventrolateral tubercles. The whorl is somewhat higher than broad, with a proportion of about 0.8 between breadth and height, but the flank is very gently inflated, passing gradually to the rounded venter; the umbilical shoulder is subrounded and the umbilical wall is low and steep. The ribs on the outer whorl are numerous, of moderate intensity, and of unequal length, with shorter ones intercalated near or branched at the umbilical tubercles. They are curved gently forward on the ventrolateral shoulder and cross the venter nearly transversely or with a slight projection. On the flank some of them are moderately sigmoidal and others less so. The ribs are separated by interspaces slightly broader than or nearly as narrow as the ribs. Periodically the interspace behind the less sigmoidal rib is somewhat deeper than others, showing an aspect of a gently prorsiradiate constriction. In the early part of the outer whorl the lower ventrolateral tubercles may remain as faint elevations on the ribs, but they disappear sooner or later. In the main part the lower as well as the upper ventrolateral tubercles are completely lost, but the umbilical tubercles persist, occurring normally at every second or third ribs.

The suture is fundamentally of Acanthoceras type, with a massive, squarish, bifid, first lateral saddle (between $\mathbf{E}$ and $\mathrm{L}$ ). The lateral lobe $(\mathrm{L})$ is deep and narrow, much narrower and slightly shorter than $\mathrm{E} ; \mathrm{U}_{2}$ is small, less than half of $\mathrm{L}$ in depth and breadth. Minor incisions are moderately deep and narrow in late growth-stages.

\begin{tabular}{|c|c|c|c|c|c|}
\hline \multicolumn{6}{|l|}{ Measurements.- } \\
\hline Specimen & Diameter & Umbilicus & Height & Breadth & B./H. \\
\hline GK. H5595 & $65.0(1)$ & $24.5(.38)$ & $25.2(.39)$ & $20.5(.31)$ & 0.81 \\
\hline$\left(-150^{\circ}\right)$ & $47.0(1)$ & $15.5(.33)$ & $19.0(.40)$ & $16.0(.34)$ & 0.84 \\
\hline GK. H5561 $\left(-150^{\circ}\right)$ & $44.0(1)$ & $14.7(.31)$ & $17.6(.40)$ & $15.4(.35)$ & 0.87 \\
\hline GK. H5600 & \multicolumn{5}{|c|}{ Ca. 37. (deformed) } \\
\hline$\left(-120^{\circ}\right)$ & $28.5(1)$ & $9.7(.34)$ & $11.2(.39)$ & $9.0(.31)$ & 0.80 \\
\hline$\left(-210^{\circ}\right)$ & $23.4(1)$ & $6.8(.29)$ & $9.6(.41)$ & $8.0(.34)$ & 0.83 \\
\hline GK. H5616 & 13.4(1) & $4.6(.34)$ & $5.4(.40)$ & $4.8(.35)$ & 0.88 \\
\hline GK. H5617 & 10.4(1) & $2.9(.28)$ & $4.5(.43)$ & $4.1(.39)$ & 0.91 \\
\hline For comparison & & & & & \\
\hline GSI. 211 (A. ushas) & $28.0(1)$ & $10.2(.36)$ & $11.8(.42)$ & $10.5(.37)$ & 0.89 \\
\hline
\end{tabular}

Variation.-GK. H5595, holotype, is $65 \mathrm{~mm}$. in diameter and certainly a mature shell, which has the body-chamber of a little over a half whorl. GK. H5561, a paratype, of about $60 \mathrm{~mm}$. in diameter, is wholly septate, and accordingly must have been about $80 \mathrm{~mm}$. in diameter at the full-growth stage. The ventrolateral tubercles disappear earlier in the former than in the latter. 
The flanks change from a flattened state to a gently inflated one in the former somewhat earlier than in the latter. Other smaller specimens also show minor differences in the proportion of breadth to height, relative size of umbilicus, and persistency of ventrolateral tubercles. More specimens are needed to make clear the extent of variation with more accuracy.

Comparison.-The present species resembles Acanthoceras amudariense ARChANGUELSKY (1916, p. 48, pl.7, figs.7-13), from the Lower Turonian of Turkestan, in the trituberculate immature stages, but the flank of the former is flatter and has weaker ribs than that of the latter. In the late growth-stages, the ribs of the former do not show such chevrons as those of the latter, but cross the venter transversely.

The holotype of Ammonites ushas SToliczkA (1864, p. 100, pl.51, fig. 2 , $2 \mathrm{a}, 2 \mathrm{~b})$, from the yellowish calcareous shale of the Utatur Group, at Odium, southern India, is very similar to the late immature shell of Sumitomoceras faustum, although it is somewhat more widely umbilicate and has broader whorls than our specimen of the corresponding size. As these differences are minor, the two nominal species could be identical. However, in SToLICzKA's specimen (GSI. 211), which one of us (T. MATsumoto) studied at Calcutta, sutures are not exposed and the outer whorl as large as the holotype of $S$. faustum is missing. Therefore, it is difficult to conclude the identity. Until better preserved topotypes are obtained, it is better to use the proposed new name for the species from Hokkaido, which in itself is distinct.

It is interesting to note that the adult shell of the present species is apparently similar to that of Kossmaticeras theobaldianum (KossmAT, 1897) and to the shell of the middle growth-stage of Mesopuzosia indopacifica MATSUмото, 1954. It would be rather surprising to know that such a discoidal, Kossmaticeras like ammonite as this species is of identical family (Acanthoceratidae) with such highly ornate, depressed ammonites like Euomphaloceras asura Matsumoto and Muramoto.

Occurrence.-Loc. Ik 1038, a cliff on the right side of the Ikushumbets, about $450 \mathrm{~m}$. downstream from the Katsurazawa dam. The specimens came from calcareous nodules contained in siltstone of the uppermost part of unit IIc, middle part of the Mikasa Formation. The associated species are Kanabiceras septemseriatum (CRAGIN), Sciponoceras kossmati (NoWAK) (emend. Matsumoto and OвATA, 1962), Inoceramus cf. labiatus (Schlotheim), etc., indicating a Lower Turonian age.

\section{Concluding Remarks}

Remarks are concisely given below primarily on the basis of the descriptions in this paper as well as those in the previous publications.

Taxonomic results.--Selected nine species described in this paper are as follows, indicating the authorship in parentheses with abbreviations, MAT.; T. Matsumoto, Mur: T. Muramoto, and TaK.: T. Takahashi.

(1) Mantelliceras japonicum, n. sp. (MAT., Mur., \& TAK.), p. 253, Pl. 25, Figs. 
1-2; Pl. 26, Figs. 1-2; Pl. 27, Figs. 1-2

(2) Mantelliceras cantianum Spath (Mat., Mur. \& TAK.), p. 256, Pl. 27, Fig. 3; Pl. 28, Fig. 1

(3) Sharpeiceras kongo, n. sp. (MAT., MUR. \& TAK.), p. 261, Pl:29, fig. 1; Pl. 30, fig. 1

(4) Acanthoceras amphibolum Morrow (MAT. \& MUR.), p. 266, Pl. 31, fig. 1

(5) Acanthoceras cornigerum CRICK (MAT., MuR. \& TAK.), p. 268, Pl.32, fig. 1

(6) Euomphaloceras meridionale (SToLiczKA) (MAT. \& MUR.), p. 272, Pl.33, Figs. 1-2; Pl. 34, Fig. 1

(7) Euomphaloceras asura, n. sp. (MAT. \& MUR.), p. 277, Pl. 35, Fig. 1; Pl. 36, Fig. 1

(8) Kanabiceras septemseriatum (CRAGIN) (MAT., MUR. \& TAK.), p. 279, Pl. 37, Figs. 1-3

(9) Sumitomoceras faustum, n. sp. (MAT. \& MUR.), p. 283, Pl. 38, Figs. 1-4

In connexion with the description of nine species, including four new ones, a new genus, Sumitomoceras, has been introduced and some other genera are revised to a considerable extent.

These are good addition to the twenty-one species described more than ten years ago (MATsumoto and Hashimoto, 1953; MAtsumoto et al., 1957). There are still more species, at least ten, which have not yet been monographed. Thus, species of the Acanthoceratidae from the Cretaceous of Hokkaido can now be said considerably numerous, in spite of the condition that we have refrained from unnatural splitting of species.

Stratigraphic sequence of acanthoceratid species in the Cretaceous of Hokkaido.-One of us (MATsumoto, 1959) has given general remarks on the zonal succession of species of ammonoid and inocerami in the Cretaceous of Hokkaido and has recently shown (MATsumoto, 1965, figs. 2-5; 1967 [in Japanese], fig. 12.4) the stratigraphic positions of selected species in the Cretaceous sequence of the Ikushumbets valley.

We have been engaged for years in a field work to make clear the biostratigraphic sequence in the last mentioned area. A sandstone quarry has been recently excavated, cutting the lower part of the Mikasa Formation on the eastern wing of an anticline. Still more artificial exposures are being extended eastward (i.e. stratigraphically upward) to construct a new road. The new outcrops have yielded more fossils of acanthoceratids, among others, some of which are described in the present paper. As these localities were not indicated in the previously published map (МАтsuмото, 1965, figs. 2 facing p. 6), a sketch map (Fig. 9) is added here.

In addition to the Ikushumbets and adjacent areas in Ishikari Province, central Hokkaido, the Abeshinai-Saku and adjacent areas in Teshio Province, northwestern Hokkaido, are places where acanthoceratid ammonites are obtainable, since there are comparatively shallow sea sediments. More scattered occurrence of acanthoceratids is known in other areas, where sediments of comparatively off-shore environments predominate.

In this paper we do not intend to explain in detail the stratigraphic 


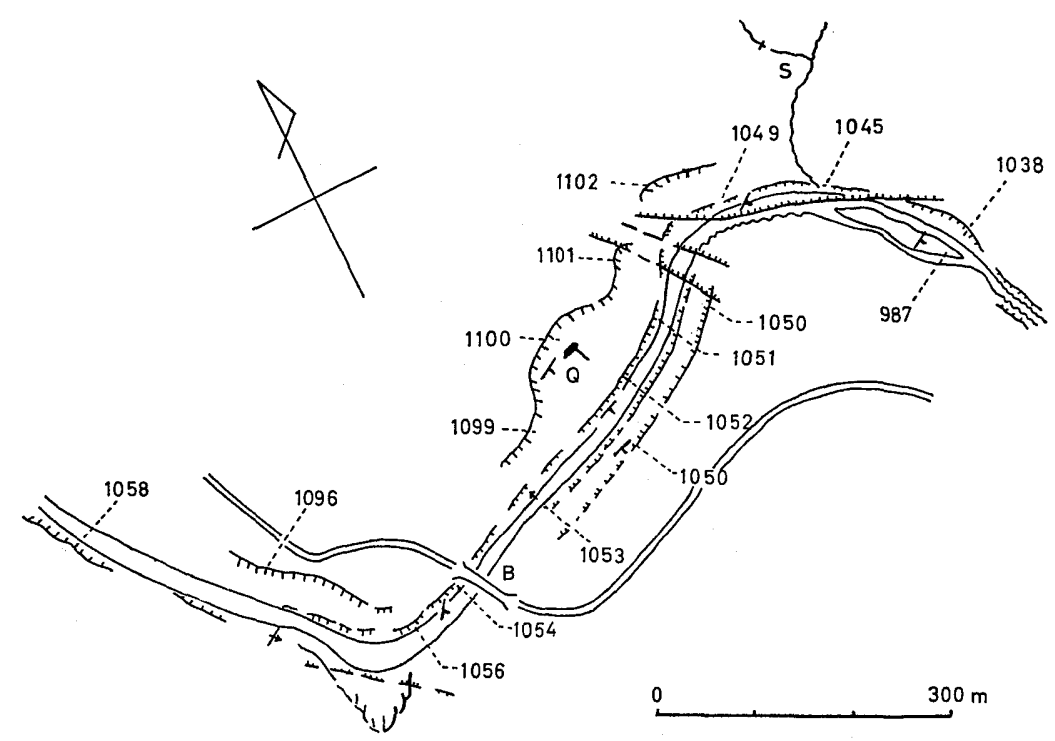

Fig. 9. Map showing location of exposures at and near the Katsurazawa quarry (Q) in the Ikushumbets valley. B: bridge called Ohashi, S: small stream called the Suido-no-sawa (indicating an unnumbered locality of Euomphaloceras sp. cf. $E$. lonsdalei with $\times$ ). See MATSUмото, 1965, fig. 2 for the map of adjacent areas.

sequence of the above areas, but show a summarized result about the succession of acanthoceratid species in the Cretaceous of Hokkaido in ascending order. (1) In the zone of Desmoceras kossmati, which is somewhat above the beds with Mortoniceras sp., in the Soeushinai-Shumarinai area, Teshio Province, occurs Graysonites sp. aff. G. adkinsi, together with Stoliczkaia sp. aff. S. dorstensis NeUmaYR, S. sp. aff. S. africana PERVINQUIÈRE, Euhystrichoceras nicaisei (CoquaND), Prionocycloides poratum (CoquAND), etc. In the same zone of the Ikushumbets valley, which is above the beds with Mortoniceras (Durnovarites) sp. and Mortoniceras (Cantabrigites) imaii (YABE and SHIMIZU), only fragmentary specimens of Graysonites have occurred. North in the Cape Soya area a large, undescribed, new species of Acompsoceras was found as a fall from the mudstone containing Desmoceras kossmati. Outside Hokkaido, one of us (Matsumoto, 1960) has already reported Graysonites sp. cf. G. fountaini Young from the bed with Desmoceras kossmati in Kyushu.

(2) In the succeeding part, typified by the lower $20 \mathrm{~m}$. of member IIb of the Mikasa Formation (eastern wing) in the Ikushumbets valley, Mantelliceras japonicum MATSUMOTo, MURAMOTo and TAKAHASHI is characteristically found, which is associated with Mantelliceras cantianum SPATH, another compressed species of Mantelliceras, and also Sharpeiceras kongo MATsumoto, MuRAmoto and TAKAHASHI. In the same unit Desmoceras poronaicum YABE, Desmoceras (Pseudouhligella) japonicum YABE, Zelandites inflatus MATsumoto, Parajaubertella imlayi MATsumoto, Turrilites costatus LAMARCK, Hypoturrilites komotai (YABE), and Sciponoceras baculoides (MANTELL) occur commonly. The as- 
semblage defines the subzone of Mantelliceras japonicum in the basal part of the broad zone of Desmoceras japonicum.

(3) This is followed by the main or middle part of the zone of Desmoceras japonicum, typified by the sandstone of the main part (about $100 \mathrm{~m}$.) of unit IIb of the Mikasa Formation, Ikushumbets valley, and the sandy siltstone of unit IIb of the Abeshinai-Saku area, in which Inoceramus concentricus nipponicus Nagao and Matsumoto is also common. This part characteristically contains Calycoceras orientale MATsUmoto, Calycoceras asiaticum (JIMBO) and Calycoceras spinosum (KoSSMAT), all belonging to the subgroup of Calycoceras newboldi (Kossmat). It can be called the subzone of Calycoceras orientale.

For some reasons the actual sequence of acanthoceratid ammonites in this part on the eastern wing of the Ikushumbets anticline apparently shows finer succession. Namely the Mantelliceras bearing silty sandstone is followed by thick sandstone beds containing abundant sepcimens of Pterotrigonia hokkaidoana (YeHARA), with intercalated silty fine sandstone. These Trigonia beds, $10 \mathrm{~m}$. or so in thickness, are not rich in ammonites, and, in turn, followed by another sequence, about $25 \mathrm{~m}$., of sandstone beds in which smaller gastropods are embedded among others, as exposed on loc. Ik 1051, Ik 1052, Ik 1050, and Ik 1102. From this part horned acanthoceratids have been collected. They are Acanthoceras amphibolum MORROW, Acanthoceras cornigerum CRICK, another, undescribed, horned Acanthoceras related to A. latum CRICK, Euomphaloceras meridionale (STOLICZKA) and $E$. cf. lonsdalei (ADKINS). Then comes another sequence of more or less silty, fine-grained sandstone beds, with intercalated thinner layers of less muddy sandstone and also glauconitic, tuffaceous sandstone, outcropping at localities Ik 1045-Ik 1050. In this part, which may be altogether $65 \mathrm{~m}$. or so thick, Desmoceras (Pseudouhligella) japonicum occurs commonly and Calycoceras orientale is found here and there. Large puzosiid species, probably referable to Puzosia and Austiniceras may be also found there.

The above described detailed succession of acanthoceratids may be apparent and does not necessarily mean that Acanthoceras amphibolum, A. cornigerum and Euomphaloceras meridionale are older than Calycoceras orientale and C. asiaticum. In other words, they may be contemporary and the apparent differentiation in occurrence may imply the difference in ecological and sedimentological conditions. The former group of horned acanthoceratids may be liable to be embedded more frequently in sediments of shallower environments and the latter group of hornless Calycoceras may be so in those of slightly off-shore environments. In the silty sandstone on the western wing of the Ikushumbets anticline, in which Calycoceras asiaticum is common, an immature specimen of Euomphaloceras meridionale was obtained along with Calycoceras bathyomphalum (Kossmat).

In the Abeshinai area two examples of Euomphaloceras cf. cunningtoni were obtained from the lower and upper parts of unit IIb and specimens of Calycoceras orientale and C. spinosum from the upper and middle parts of IIb. In the Shiyubari area, where more fine-grained sediments of probably off-shore facies predominate, Calycoceras orientale and Calycoceras cf. stoliczkai CoLLIG- 
NON have been found in the middle part of the zone of Desmoceras japonicum. (4) The succeeding zone is the upper part of the broad zone of Desmoceras japonicum and typified by the main part, about $50 \mathrm{~m}$. siltstone of member IIc (uppermost $10 \mathrm{~m}$. excluded) of the Mikasa Formation (on the eastern wing) in the Ikushumbets valley. Large shells of Inoceramus of concentricus group, i.e. Inoceramus pennatulus PERGAMENT and related forms, commonly occur in this part, while acanthoceratids are few. The identified species are Calycoceras naviculare (MANTELL), Eucalycoceras pentagonum (JUKES-Browne) and Protacanthoceras sp. Large puzosiid ammonites, probably of Pachydesmoceras and Austiniceras may be found here and there.

Unit IIb-c of the Abeshinai-Saku area, from which Euomphaloceras asura MATSUMото and MURAмото was obtained, is probably correlated with this part for the reason of the stratigraphic position and also of the association of Inoceramus pennatulus.

(5) The assemblage of species in the uppermost $10 \mathrm{~m}$. of member IIc of the Ikushumbets area is different from that in the main part of the same member described above, inspite of the similarity in lithology. It is characterized by Kanabiceras septemseriatum (CRAGIN) and Sumitomoceras faustum MATsumoto and MuRAMoto, and accompanied Sciponoceras kossmati (NowAK) and Inoceramus labiatus (SchloтнеiM). In the Yamabe-Kanayama area, about $35 \mathrm{~km}$. east from Ikushumbets across the Yubari range, Pseudaspidoceras sorachiense MATSUMOTо and HAsHimoto was found in the bed with Inoceramus labiatus.

Unit IIc in the Abeshinai-Saku area is probably correlated with the above mentioned parts in the Ishikari Province, but from that unit only a fragmentary whorl of Kanabiceras cf. septemseriatum has been obtained. It contains Fagesia thevestensis (PERON), a vascoceratid, among others.

(6) In the succeeding part, sandstones of unit IId in the Ikushumbets area, no acanthoceratid has been found. It is divided to the zone of Inoceramus hobetsensis below and that of Inoceramus teshioensis above. In the Hatonosu dome of the Yubari area an undescribed species of Romaniceras occurs in the zone of I. hobetsensis. In the Shiyubari-Hobets area, east of Yubari, Romaniceras aff. uchauxiense CoLLIGNoN, Romaniceras (?) otatumei MATSUmoto, SAITo and FuKada, Yubariceras yubarense MATsumoto, SAIto and FUKADA and probably also Yubariceras sp. aff. $Y$. (?) adkinsi (JoNEs) show scattered distribution in the zone of Inoceramus hobetsensis. Although Romaniceras and Yubariceras have longer ranges, the successive sequence of species have not yet been precisely known. Examples in Japan seem to occur rather commonly in the zone of Inoceramus hobetsensis, with which Subprionocyclus neptuni (GEINITZ) is often associated. The exact stratigraphic position of Romaniceras pseudodeverianum (ЈIмво) is not known.

(7) To sum up, on the basis of the assemblage of characteristic species, the above explained zonal succession in the Cretaceous sequence of Hokkaido can be correlated with the following stages or substages in terms of international scale:

1. Zone of Desmoceras kossmati containing Graysonites aff. adkinsi, etc.: Basal Cenomanian [lower Lower Cenomanian] 
2. Lower part of the zone of Desmoceras japonicum=subzone of Mantelliceras japonicum: Lower Cenomanian [upper Lower Cenomanian]

3. Middle part of the zone of Desmoceras japonicum=subzone of Calycoceras orientale-Euomphaloceras meridionale: Middle Cenomanian (as defined by HANCOCK, 1959) [lower Upper Cenomanian by some authors]

4. Upper part of the zone of Desmoceras japonicum=subzone containing Calycoceras naviculare: Upper Cenomanian [upper Upper Cenomanian]

5. Zone of Inoceramus labiatus-Kanabiceras septemseriatum: Lower Turonian

6. Zone of Inoceramus hobetsensis, containing several species of Romaniceras and Yubariceras: Middle Turonian [=lower Upper Turonian by some authors]

7. Zone of Inoceramus teshioensis, with subzone of Subprionocylus normalis below and that of Reesidites minimus above (No acanthoceratid has been found): Upper Turonian [=upper Upper Turonian by some authors]

The above conclusion may be still tentative, for it involves some unsettled points. Although the succession of the species, or better to say the succession of the assemblage of characteristic species, in the Cretaceous of Hokkaido is generally in harmony with that in other well studied regions, such as western Europe, Western Interior-Gulf Coast of North America, California, Madagascar and other areas, the details are not quite identical. For brevity we would not explain here at length those provincial dissimilarities. How they are explained and what is the most reliable conclusion of interregional correlation are the problem to be still worked out. Anyhow, the zonal succession established in the Cretaceous of Hokkaido would be one of the good reference scales for the international correlation and the acanthoceratids afford good evidence for the problem.

Notes on the evolutional history of the Acanthoceratidae (by Tatsuro Matsumoto)

(1) The Acanthoceratidae include various forms but seem to be monophyletic, having their ultimate origin in Stoliczkaia (Lyelliceratidae) of late Albianearly Cenomanian ages. Their extent of variability or divergency is considerably great, as is exemplified below.

(2) Stoliczkaia itself is a rather small, compressed, less strongly ornamented ammonite. Its immediate derivatives Submantelliceras and Utaturiceras are still compressed and small to moderate in size. Mantelliceras, a probable successor of Submantelliceras, includes compressed to moderately inflated species, with moderately strengthened ribbing and tuberculation. Its size at the adult stage is in most cases moderate, nearly or less than $130 \mathrm{~mm}$. in diameter, but may become exceptionally large as in $M$. nagaoi Matsumoto, SAIto and FuKadA (1957, pl. 12).

(3) Sharpeiceras is probably another descendant from Submantelliceras rather than that from Mantelliceras, acquiring evolute, subrectangular shell-form, regularly arranged, predominant tubercles and fairly complex sutures. Its adult whorl may become very large and show hypernodosity in some species, as 
beautifully illustrated by Sharpeiceras kongo.

(4) The hypernodosity appears also on the adult whorl of Graysonites, while in Acompsoceras the adult whorl becomes smoothish. The two genera were probably derived from a common ancestor, Stoliczkaia directly or by way of Submantelliceras. They have complex sutures consisting of numerous elements (see MAtsumoto et al., 1960, 1966) and include species of large size.

(5) On the other hand Cottreauites and Neopulchellia are small and finely ornamented, although the hitherto described species may be based on immature shells. They have also numerous sutural elements. (There are no examples from Hokkaido.)

(6) Thus, in the early phase of the evolutional history of the Acanthoceratidae, in early Cenomanian, at least eight taxa of generic rank have already been diverged, of which Submantelliceras and Mantelliceras form a main stock, leading to later genera, but others are short branches or offshoots and deadended, without giving rise to descendants.

(7) Calycoceras, of middle to late Cenomanian ages, was directly derived from Mantelliceras, acquiring the siphonal row of tubercles in the early to middle growth-stages. It includes not only the species of rounded whorl but also those of depressed whorl, some of which may reach a considerably large size. Eucalycoceras is probably a descendant of Calycoceras, acquiring more involution and compression of whorls and denser ribbing. It includes species of moderate size.

Less well known Paracalycoceras (of Lower Cenomanian), with weaker ventral tubercles on the inner whorls and rursiradiate ribs on the outer whorl, and Tunesites [=? Hourcquiceras], with marked constrictions, are probably offshoots from the main stock of Mantelliceras-Calycoceras.

(8) As these genera are intimately connected with Mantelliceras, they have been assigned to the subfamily Mantelliceratinae. They differ, however, considerably from various, early Cenomanian offshoots of Stoliczkaia-Submantelliceras. Therefore it would be desirable to group the latter into another subfamily, which commonly have more or less involute and compressed whorls, bituberculate venter and numerous, typically fairly deeply incised sutural elements. The proposed subfamily is named here Utaturiceratinae MATsUmoTo, nov., which include Submantelliceras, Utaturiceras, Graysonites, Acompsoceras, Cottreauites and Neopulchellia.

(9) In the genera mentioned in (7) the ribs are as a rule dominant over tubercles. On the last whorl the ventral tubercles are weakened and may be finally absorbed by the ribs. This has been similarly noticed in Mantelliceras.

In the typical genera of the Acanthoceratinae the tubercles predominate over tubercles. Acanthoceras itself is certainly derived from Calycoceras, acquiring squarish whorl section. On the outer whorl of certain species of Acanthoceras ventrolateral horns are developed as in some species of Sharpeiceras. Acanthoceras gave rise to Euomphaloceras, with multiplication of ventral ornaments. The latter, in turn, led to Kanabiceras, with projection of ventral ribs and formation of a nodose siphonal keel at least in certain growth-stages. 
Euomphaloceras and Kanabiceras have ventrolateral horns or spines. The former is large but the latter is reduced in size.

(10) While Euomphaloceras and Kanabiceras have depressed shell form, Protacanthoceras is compressed and rather small, having approximated ventral clavi. Whether it is a derivative of Eucalycoceras or Acanthoceras may be questionable, but a certain, undescribed species Protacanthoceras in C. W. WRIGHT's collection seems to indicate closer affinity with Acanthoceras. Neocardioceras, of the Lower Turonian, a probable descendant from Protacanthoceras, with fastigate venter, has a row of close siphonal tubercles, which tend to form a nodose keel. It is considered as a possible ancestor of the Collignoniceratidae, although no example of Neocardioceras has been found from the Cretaceous of Hokkaido.

(11) Neosaynoceras, known from the Lower Cenomanian of Africa, is unusually smaller than other acanthoceratids. It is a homoeomorph of Saynoceras, but how it is connected with Acanthoceras is not precisely known. No example has been found in Japan.

(12) Dunveganoceras, from the uppermost part of Cenomanian, is another aberrant acanthoceratid genus, showing on its large outer whorl dominant rounded ribs, ventrolateral horns, or bulges, or flares, which may form wall like ribs. Similar, if not identical, ventrolateral flares are developed on the last part of the outer whorl of Euomphaloceras asura described in this paper. We are not yet successful in obtaining examples of Dunveganoceras from Japan.

(13) Watinoceras of the Lower Turonian, is a rather small, compressed acanthoceratid genus, which has double ventrolateral tubercles. It is apparently similar to Mantelliceras, but has in its early immature shell siphonal row of tubercles. It is probably a derivative of Neocardioceras and is assigned to Mammitinae because of its affinity with Mammites. In a new genus, Sumitomoceras, the ventral tubercles are lost in middle to late growth-stages. It is a homoeomorph of Kossmaticeras, but is in sisterhood relation with contemporary Watinoceras, because they closely resemble each other in the immature stages. Bunueites is another relative of Watinoceras, which has its own particular characters. It is reported from Nigeria (REYMENT, 1954) and has not been found from Japan.

(14) Other, more typical genera of Mammitinae, such as Mammites, Pseudaspidoceras and Metasigaloceras, have more prominent tubercles, which may form horns in some species, and may reach a larger size. They all have no siphonal tubercles and their sutures are a little simpler than those of most Acanthoceratinae.

(15) Metoicoceras is a compressed and involute derivative of Acanthoceras, with weakening of tubercles and modification of sutures to pseudoceratitic type. It includes several species of uppermost Cenomanian to lower Turonian ages, and represents the Metoicoceratinae. For some reasons no example of this widespread genus has been found in Japan, as in the case of other pseudoceratites. (16) Romaniceras, a multituberculate derivative of Calycoceras appears in late Cenomanian and ranges up to late Turonian. In its outer whorl the tubercles 
may be absorbed by predominant ribs as in that of Calycoceras. In parallel with this there is Yubariceras*, a multituberculate derivative of Acanthoceras. Likewise there could be multituberculate derivatives of Eucalycoceras and Tunesites, but the evidence is yet insufficient.

(17) In many of the genera of the Acanthoceratidae, such as Mantelliceras, Sharpeiceras, Calycoceras, Eucalycoceras, Acanthoceras, Euomphaloceras, Kanabiceras, Protacanthoceras, Romaniceras, Metoicoceras and Mammites, the generic diagnosis is most remarkably manifested in comparatively middle growth-stages of ontogeny. In more or less early immature stages the character of a genus is as a rule common with or similar to that of the young to middle growth-stages of its ancestral genus. However, in several genera a new character appears in early growth-stage, such as the double ventrolateral tubercles in Stoliczkaia, the increase in the number of sutural elements in Submantelliceras, the siphonal row of tubercles in Calycoceras, and the nodose keel in Neocardioceras, each of which has potentiality of leading to more descendants of a family or subfamliy group.

In some cases the distinction between related genera becomes less clear in the late growth-stage, as between Mantelliceras and Calycoceras, or Calycoceras and Romaniceras, or Acanthoceras and Euomphaloceras, or Euomphaloceras and Kanabiceras, the outer whorls of two of the combination being similar to each other. There are, however, some genera in which the distinction becomes clearer in rather later growth-stages, such as Utaturiceras, Graysonites, Dunveganoceras, Sumitomoceras and Pseudaspidoceras. They are all offshooted deadends, showing deviation from the allied genera.

(18) The multiple divergency of the Acanthoceratidae probably implies the adaptive radiation as well as the orthogenetic evolution. Various types of shellform, ornamentation and sutures may be respectively related to certain modes of life and ecological conditions of animals. How a particular character, e.g. a complex or simple suture, rounded or squarish whorl, strong and rigid or weak and flexuous ribbing, horn-like, or flared, or multiple tuberculation, was related to what kind of habitat and acted in what sort of living ought to be made clear. The similarity in mode of life may give a similar character. Thus, a horned body-whorl occur in a number of species which are not necessarily directly related to one another, such as certain species of Graysonites, Sharpeiceras, Acanthoceras, Euomphaloceras, Dunveganoceras and Mammites. A moderately ribbed outer whorl with feeble or no ventral tubercles is seen in many species of Mantelliceras, Calycoceras, Romaniceras and some of Eucalycoceras, Sumitomoceras and Metoicoceras. A smoothish body-whorl is found in some species of Stoliczkaia, Acompsoceras, Eucalycoceras and Metoicoceras. The change of shell characters in most acanthoceratids may be related to the change of living conditions with growth. These involve further problems to be studied.

\footnotetext{
* Schindewolfites WIEDManN, 1959, can be included in, or possibly immature form of, Yubariceras Matsumoto, SaIto and Fukada, 1957.
} 


\section{References Cited}

Adkins, W. S. (1928): Handbook of Texas Cretaceous fossils. Univ. Texas Bull., 2838, 303 p., 37 pls., index.

(1931): Some Upper Cretaceous ammonites in western Texas. Univ. Texas Bull., 3101, 35-72, pls. 2-5.

Anderson, F. M. (1958): Upper Cretaceous of the Pacific Coast. Geol. Soc. Amer., Memoir 71, 378 p., 75 pls.

Arkhanguelsky, A. D. (1916): Mollusques du Crétacé supéprieur de Turkestan. Mém. Com. Géol. Petrograd, [N.S.], livr. 152, i-vi, 1-57, pls.1-8.

Benavides-CÁCeres, V. E. (1956): Cretaceous system in northern Peru. Bull. Amer. Mus. Nat. Hist., 108, (4), 353-494, pls. 31-66.

BöSE, Emil (1928): Cretaceous ammonites from Texas and northern Mexico. Univ. Texas Bull., 2748, [for 1927] 143-357, pls.1-19.

Choffat, P. (1903-5) : Contributions a la connaissance géol.des colonies portugaises d'Afrique. I. Le Crétacique de Conducia, 1903, 1-29, $7 \mathrm{pls.,} 1$ folded pl.; II. Nouvelles données sur la zone litorale d'Angola, 1905, 1-45 [31-75], pls. 1-4. Commiss. Serv. géol-Portugal.

Cobban, W. A. and ReEside, John B. Jr. (1952): Correlation of the Cretaceous formations of the Western Interior of the United States. Bull. Geol. Soc. Amer., 63, 1011-1044, 1 pl.

Collignon, Maurice (1937): Ammonites cénomaniennes du Sud-Ouest de Madagascar. Ann. Géol. Ser. Mine, Madagascar, 8, 31-69, pls. 1-11. (1964): Atlas des Fossiles Caracteristiques de Madagascar (Ammonites). 11, Cenomanien, 152 pp., pls. 318-375.

Coquand, H. (1862): Géologie et paléontologie de la région sud de la province de Constantine. Mém. Soc. d'Emul. Provence, 2, 341 pp., 36 pls.

CRAGIN, F. W. (1893): A contribution to the invertebrate palaeontology of the Texas Cretaceous. Geol. Surv. Texas, 4th Annual Report [1892], 139-294, pls. 24-46.

CRICK, G. C. (1907) : Cretaceous fossils of Natal, Part 3. Third and Final Report of the Geol. Surv. Natal and Zululand, 161-262, pls. 10-15.

GUERANGER, E. (1867): Album paléontologique de department de la Sarthe, 20 pp., 25 pls., Le Mans.

Grossouvre, Albert DE (1894): Recherches sur la Craie supérieure. II Paléontologie. Les ammonites de la Craie supérieure. Mém. Carte géol. dét. France [1893], 264 p., 39 pls.

HaNCock, J. M. (1959): Les ammonites du Cénomanien de la Sarthe. $84^{e}$ Congrés des Soc. savantes, 1959, 249-252.

Henderson, J. H. (1908): New species of Cretaceous invertebrates from northern Colorado. U. S. Nat. Mus. Proc., 34, 259-264, pl. 13.

Hyatt, Alpheus (1903): Pseudoceratites of the Cretaceous. Edited by T. W. StanToN. Monogr. U. S. Geol. Surv., 44, $351 \mathrm{p}, 47 \mathrm{pls.}$

JELETZKY, J. A. (1968): Macrofossil zones of the marine Cretaceous of the Western Interior of Canada and their correlation with the zones and stages of Europe and the Western Interior of the United. States. Geol. Surv. Canada, Paper 67-72, 1-66, 2 charts.

Kellum, L. B. and Mintz, L. W. (1962): Cenomanian ammonites from the Sierra de Tlahualilo, Coahuila, Mexico. Contr. Mus. Paleont., Univ. Michigan, 13, 267-287, pls. 1-8.

Kossmat, Frantz (1895): Untersuchungen über die Südindische Kreideformation, I. Beitr. Paläont. Geol. Österr.-Ungarns u.d. Orients, 9, 97-203 [1-107], pls. 1525 [1-11].

Mantell, G. (1822): Fossils of the South Downs. 320 p., 43 pls., London.

Matsumoto, Tatsuro (1942-43): Fundamentals in the Cretaceous stratigraphy of Japan. Part I. Mem. Fac. Sci., Kyushu Imp. Univ., [D], 1, 129-280, pls. 5-20 (1942) ; Parts II \& III. Ibid., 2, 97-237 (1943). 
(1954) : Family Puzosiidae from Hokkaido and Saghalien. Mem. Fac. Sci., Kyushu Univ., [D], 5, (2), 69-118, pls. 9-23.

(1959a): Zonation of the Upper Cretaceous in Japan. Mem. Fac. Sci., Kyushu Univ., [D], 9, (2), 55-93, pls. 6-11.

(1959-60): Upper Cretaceous Ammonites of California Parts I-III. Mem. Fac. Sci., Kyushu Univ., [D], 8, (4), 91-171, pls. 30-45 (1959b) (Part I) ; Ibid., Special Vol.1, 1-172, pls. 1-41 (1959c) (Part II) ; Ibid., Special Vol.2, 1-204, pls. 1-2 (1960a) (Part III).

(1960b): Graysonites (Cretaceous Ammonites) from Kyushu. Mem. Fac. Sci., Kyushu Univ., [D], 10, (1), 41-58, pls. 6-8.

(1965): A monograph of the Collignoniceratidae from Hokkaido. Part I. Mem. Fac. Sci., Kyushu Univ., [D], 16, (1), 1-80, pls. 1-18.

(1967) : Cretaceous. In Asano et al., Historical Geology, 2, 408-477, Asakura Shoten, Tokyo (in Japanese).

Matsumoto, Tatsuro and Hashimoto, Wataru (1953): A find of Pseudaspidoceras from Hokkaido, Japan. Trans. Proc. Pal. Soc. Japan, [N.S.], (12), 97-102, pls. 10.

and OватA, Ikuwo (1962): A monograph of the Baculitidae from Japan. Mem. Fac. Sci., Kyushu Univ., [D], 13, (1), 1-116, pls. 1-27.

and - (1966): An acanthoceratid ammonite from Sakhalin. Bull. Nat. Sci. Museum, 9, (1), 43-52, pls. 1-4.

and SARKar, S. S. (1966): Notes on some Cretaceous ammonites from southern India. Mem. Fac. Sci., Kyushu Univ., [D], 17, (3), 297-309, pls. 32-33.

, SaIto, Rinji and FuKada, Atsuo (1957): Some acanthoceratids from Hokkaido. Mem. Fac. Sci., Kyushu Univ., [D], 6, (1), 1-45, pls. 1-18.

Moreman, W. L. (1927): Fossil zones of the Eagle Ford of north Texas. Jour. Paleont., 1, 89-101, pls. 13-16.

(1942) : Paleontology of the Eagle Ford Group of north and central Texas. Jour. Paleont., 16, 192-220, pls. 31-34.

Monnow, A. L. (1935): Cephalopods from the Upper Cretaceous of Kansas. Jour. Paleont., 9, 463-473, pls. 49-53.

OrLov, Yu. A. [Ed.] (1958): Principles of palaeontology, 6, Mollusca, Cephalopoda, ii, Ammonoidea, Dibranchiata [in Russia], 359 pp., 71+7 pls., Moscow.

Peron, Alphonse (1896-97): Les ammonites du Crétacé supérieur de l'Algérie. Mém. Soc. Géol. France, Paléont., 6, (4), 1-24, pls. 14-19 (1896); 7, (1-2), 25-88, pls. 1-12 (1897).

Pervinquière, L. (1907): Etudes de paléontologie tunisienne. I Céphalopodes des terrains sécondaires. Carté géol. Tunise, 428 p., 27 pls.

Petrascheck, W. (1962): Die Ammoniten der sächsischen Kreideformation. Beitr. Geol. Paläont. Oesterr.-Ungarns u.d. Orients, 14, 131-152, 5 pls.

Reeside, J. B. Jr. and Weymouth, A. A. (1931): Mollusks from the Aspen Shale (Cretaceous) of southwestern Wyoming. Proc. U. S. Nat. Mus., 78, Art 17, (2860), 1-24, pls. 1-4.

SchlÜTER, Clement (1871-76): Die Cephalopoden der oberen deutschen Kreide. Palaeontographica, 21, 1-24, pls.1-8 (1871); 25-120, pls. 9-35 (1872); 24, 121-264, pls. 36-55 (1876).

Sharpe, Daniel (1853-57): Description of the fossil remains of mollusca found in the Chalk of England. Palaeontogr. Soc., 68 pp., 27 pls. (1-26, pls.1-10, 1853; 27-36, pl. 11-16, 1855; 37-68, pls. 17-27, 1857).

Spath, L. F. (1923) : On the ammonite horizons of the Gault and contiguous deposits. Summ. Progr. Geol. Surv. (1922), 139-149.

(1925): On Upper Albian Ammonoidea from Portuguese East Africa, with an appendix on Upper Cretaceous ammonites from Maputoland. Ann. Transvaal Museum, 11, (4), 179-200, pls. 28-37.

(1926a): On new ammonites from the English Chalk. Geol. Mag., 63, 77-83. (1926b). On the zones of the Cenomanian and the Uppermost Albian. Proc. 
Geol. Assoc., 37, 402-432.

Stanton, T. W. (1894): The Colorado Formation and its evertebrate fauna. Bull. U. S. Geol. Surv., 106, 288 p., includ. 45 pls. (1893).

STEPHENson, L. W. (1953): Larger invertebrate fossils of the Woodbine Formation (Cenomanian) of Texas. U. S. Geol. Surv. Prof. Paper, 242, 226 pp., 59 pls. (1952).

Stoliczka, Ferdinand (1863-66) : Ammonitidae, with revision of the Nautilidae, etc. In Blanford, M. F., and StoliczKA, F., 1861-66. The fossil Cephalopoda of the Cretaceous rocks of southern India. Mem. Geol. Surv. India, Palaeont. Indica, [3], 216 p., 95 pls. [41-56, pls. 26-31, 1863; 57-106, pls. 32-54, 1864; $107-154$, pls. 55-80, pl. 66a, 1865; 155-216, pls. 81-94, 1866$]$.

WARren, P. S. (1930) : Description of new species of fossils from parts of the Peace River and Grande Prairie districts, Alberta. Sci. Ind. Res. Council of Alberta, Rep. (21), Appendix, 57-68, pls. 1-4.

and STElCK, C. R. (1940): Cenomanian and Turonian faunas in the Pouce Coupe district, Alberta and British Columbia. Trans. Roy. Soc. Canada, [IV], 34, 143-152, pls. 1-4.

and (1955): New Cenomanian ammonites from Alberta. Appendix in STELCK, C. R. and WARREN, P. S., Formainifera of the Cenomanian Dunvegenoceras zone from Peace River area of Western Canada. Research Council of Alberta, Report No. 70, p. 63-80, pls. 4-9.

Wiedmann, Jost (1959): Le Crétacé supérieur de l'Espagne et du Portugal et ses céphalopodes. $84^{e}$ Congrés des Société savantes, 1959, 709-764, includ. pls. 1-8.

WRIGHT, C. W. (1957): In MOORE, R. C. [Editor]: Treatise on Invertebrate Palaeontology, Part L. Mollusca, Cephalopoda, Ammonoidea, L1-L490, Geol. Soc. Amer. \& Univ. Kansas Press.

(1956): Notes on the Cretaceous ammonites. III. Utaturiceras gen. nov. and the Metoicoceratinae. Ann. Mag. Nat. Hist., [12], 9, 391-393.

(1963): Cretaceous ammonites from Bathurst Island, Northern Australia. Palaeontology, 6, (4), 597-614, pls. 81-89.

and WRIGHT, E. V. (1951): A survey of the fossil Cephalopoda of the Chalk of Great Britain. Primarily a nomenclatorial revision of Daniel SHARPE's "Description of the fossil remains of mollusca found in the Chalk of England, Part I. Cephalopoda" (1853-1857). Palaeontogr. Soc. (1950), 40 p.

YABE, Hisakatsu (1926): A new scheme of the stratigraphic subdivision of the Cretaceous deposits of Hokkaido. Proc. Imp. Acad., Japan, 2, (5).

Young, Keith (1958): Graysonites, a Cretaceous ammonite in Texas. Jour. Paleont., 32, (1), 171-182, pls. 27-29. 